\title{
PUERTO RICAN ORNITHOLOGICAL RECORDS
}

By Stuart T. Danforth

College of Agriculture of the University of Porto Rico, Mayagïez, $P . R$.

In 1926 I published in the Journal of the Department of Agriculture of Porto Rico a paper entitled "Birds of the Cartagena Lagoon, Porto Rico". This paper included my observations until 1924 on the birds of the lagoon referred to, also such other notes as I had from other parts of the island concerning species which were also found at the lagoon. The present paper is intended to be complementary to the Cartagena Lagoon paper. It includes such information as I have obtained since 1924 regarding the birds discussed in the previous paper, and in addition any information that $I$ have concerning those species which were not mentioned in that paper. I have endeavoured as far as possible not to repeat any information previously published. However, for the sake of completeness, I have listed all the birds that I have observed in the island. In the few cases where I have not obtained any additional information on a species, I simply refer to the previous paper. Also, in order to make a more inclusive summary of migration dates, all the migration dates that I have are listed. With these small exceptions, no information has been repeated.

The information included in this paper is based upon the following periods of time which the author has spent observing birds in Porto Rico, during which he has visited every town on the island: From October 1921 to June 1922; November 1923 to October 1924; and from September 1926 to the present writing in 1930, with the exception of two or three months during each summer, and occasional shorter periods in the Christmas vacations when other islands were visited.

In company with a number of his students the writer spent three days (May 7-9, 1927) on Desecheo Island. The observations made on that trip are also recorded in this paper.

The accompanying map shows only those localities at which I have collected or observed birds. Practically every locality to which reference is made in the paper which follows will be found upon this map.

Under each species I have attempted to give the English and Spanish names in actual use, followed by such notes as I have ob- 
tained on habits, nesting, food, and migration; also a list of the localities in Porto Rico at which I have observed each species, and a catalogue of the examples of each from Porto Rico which I now have in my collection. This collection is at present deposited at the College of Agriculture of the University of Porto Rico at Mayagüez. The catalogue does not include those specimens which I have collected but which are now in other collections. Most of the specimens to which reference is made in my former paper are now in the collection of Cornell University. A few specimens collected since then have been sent to some four or five other institutions.

The writer wishes to express his thanks to Mr. John T. Emlen, Jr., of Philadelphia, for permission to reproduce a few of the photographs which he took during a short visit to the island.

\section{COLYMBUS DOMINICUS DOMINICUS (Linné). Least Grebe. Tigua.}

Least Grebes are common birds on the larger fresh water lagoons of the island, and are found occasionally on some of the reservoirs. I have found them regularly at Cartagena, Anegado and Guánica Lagoons. On March 24, 1929 I observed eight at the Coamo Springs Reservoir, and on November 30, 1929 one at the Guayabal Reservoir.

At Anegado Lagoon on September 29, 1926 I observed a pair of Least Grebes accompanied by five downy young, which were riding on the back of one of the parents. The parent with the young on its back hid for half an hour behind a pond lily leaf which was blown into a vertical position by the wind. After observing them for some time I walked slowly towards them. The parent suddenly dove and the young scattered swimming in all directions under water. I succeeded in catching one of them as it came up for air. The young birds uttered faint whistling peeps.

Porto Rican specimens now in my collection:

No. 1, male, Cartagena Lagoon, Sep. 9, 1924.

No. 2, female, Cartagena Lagoon, Sep. 17, 1924.

No. 3, downy young, Anegado Lagoon, Sep. 29, 1926.

\section{PODILYMBUS PODICEPS ANTILLARUM Bangs.} Antillean Pied-billed Grebe. Zaramago.

This grebe is much more generally distributed in Porto Rico than the Least Grebe, being found in some of the larger river marshes as well as in the fresh water lagoons. I have found it common at Cartagena Lagoon, Anegado Lagoon, Guánica Lagoon, the Isabela 
Irrigation Reservoir, and the Guayabal Reservoir. When the Coamo Springs Reservoir is full $I$ have observed as many as fifty there, and whenever there is any water at least a few may be found. On December 29, 1929 I saw one in the river marshes at Arecibo, and on March 7, 1927 a pair on the brackish water Laguna Tortuguera.

The stomach of an example collected at Cartagena Lagoon was almost completely filled with feathers. The only food that it contained was a few fragments of creeping water bugs (Pelocoris femoratus), which amounted to only 3 per cent of the stomach contents.

Porto Rican specimen now in my collection:

No. 669, female, Cartagena Lagoon, Nov. 18, 1928.

\section{OCEANITES OCEANICUS (Kuhl). Wilson's Petrel.}

The Wilson's Petrel undoubtedly occurs frequently offshore during the summer, but it does not seem to have been definitely known from Porto Rico until I recorded (Bulletin of the Northeastern Bird Banding Association, Vol. 3, 1927, p. 59) an example seen two miles west of Rincón Point on May 9, 1927. More recently, on a trip from San Juan to New York, Wilson's Petrels began following the steamer when we were about fifteen miles north of San Juan. This was on May 23, 1928.

\section{PHAETHON LEPTURUS CATESBYI Brandt. Yellow-billed Tropic}

Bird. Caracolera. Gaviota de Rabo Largo.

About a dozen pairs of these birds (known locally as Caracoleras) nest every year at some precipitous limestone cliffs east of the mouth; of the Guajataca River between Isabela and Quebradillas. Near this locality a number of individuals can be seen any day during the breeding season, which is apparently from April to July. On one occasion I was shown a large dome-shaped cave the roof of which had fallen in. There were little niches in the walls of the dome in which I was told the birds nest, but at that time it was too early in the season for any birds to be nesting. The earliest date at which I have observed the species at this locality is March 9, 1930, although I am told by people residing in the region that they arrive by the middle of February.

On March 22, 1929 I observed a pair circling around over the water near Tallaboa, on the south coast. Suddenly one flew into a hole in an inaccessible position in a high cliff near the shore, from which it could not be persuaded to emerge even upon firing a shot in close proximity to the hole. 


\section{PELECANOS OCCIDENTALIS OCCIDENTALIS Linné. \\ Brown Pelican. Aleatraz.}

The Brown Pelican is a very common bird along the coasts of Porto Rico at all times of the year. I have never found it breeding on the main island, but it is a fairly common breeder on small islets off the coast. About forty pairs nest on Cayo Enrique, a small mangrove island near Parguera. On April 2, 1927 forty nests were found in the tops of the mangroves from eighteen to twenty feet above the ground. At that time each nest contained two enormous dirty white eggs. Apparently the nesting season is not very regular, since on a visit to the same colony on March 22, 1928 I found that most of the nests had young ranging in size from newly hatched birds to those nearly ready to fly. Also one nest with two much soiled eggs nearly ready to hatch, and another with one fresh white unincubated egg were found on this date. The young Pelicans in thenests thrust their bills viciously at intruders, but they were incapableof inflicting much injury. On August 15, $1927 \mathrm{Mr}$. John T. Emlen, Jr., and the author visited the same colony. On this occasion we found that most of the nests contained well grown young, but a few nests with smaller young and one with three eggs were found. Many immature birds with white heads were flying around, and they frequently alighted on the mangroves beside the nests.

Brown Pelicans are almost never found at fresh water, but on March 23, 1929 I noted one perched in the marsh at the edge of the open water on the Coamo Springs Reservoir.

Localities at which I have observed Pelicans are: Aguadilla, Aguada, Rincón, Añaseo, Mayagüez, Joyuda, Rat Island, Puerto Real, Boquerón, Faro de Cabo Rojo, Parguera, Cayo Enrique, Ensenada, Guayanilla, Tallaboa, Ponce, Pastillo, Coamo Springs Reservoir, Salinas, Playa de Naguabo, Fajardo, Mameyes, Río Piedras, San Juan, Hatillo, Arecibo and Quebradillas.

\section{SULA LEUCOGASTRA LEUCOGASTRA (Boddaert). Common Booby. Pájaro Bobo.}

The Booby is a common bird off the coasts of Porto Rico, usually keeping offshore, but occasionally perching on rocks along the coast.

From May 7 to 9, 1927 I visited the breeding colony of this species on Desecheo Island. At that time it was decidedly the most abundant bird on the island. It was very difficult to count them, but I believe fifteen thousand birds to be a safe estimate. At the time of my visit the nests contained young in all stages of develop- 
ment. Most of them had passed the downy stage, and no eggs were found. The birds were nesting all over the island from the seabeach to the top of the highest mountain, but most abundantly within two hundred feet of the shore. Young birds which were nearly full sized, but could not yet fly, would bite viciously at persons walking near them. A fisherman who accompanied our little expedition would on such occasions give the offending bird a kick into the cactus or other nearby brush. Large numbers of adults were fishing a short distance offshore, where they were being continually harassed and robbed by Man-o-war Birds. When passing by Desecheo in a boat on August 10, 1927 I observed many fishing near the island.

On the main island of Porto Rico I have observed Boobies at Point Borinquen, Aguadilla, Aguada, Rincón, Mayagüez, Joyuda. Puerto Real, Faro de Cabo Rojo, Fajardo, and Hatillo.

Porto Rican specimens now in my collection:

No. 399, female, downy young, Desechèo, April 21, 1927.

No. 400, female, adult, Desecheo, May 7, 1927.

No. 715, Immature, Mayagïez, Feb. 15, 1929.

\section{SULA PISCATOR (Linné). Red-footed Booby. Pájaro Bobo.}

The Red-footed Booby is scarce off the coasts of Porto Rico, but there is a small breeding colony on Desecheo Island.

On August 10, 1927 I observed five adults and ten brown young with white tails feeding a short distance off Point Borinquen, the northwest corner of Porto Rico. On December 2, 1929 I observed an adult diving for fish about half a mile offshore at Joyuda.

From May 7 to 9, 1927 I made observations of the breeding colony on Desecheo Island. All the birds of this species, (about fifty pairs) bred in a small area about a hundred and fifty feet back from the southern shore of the island. Their nests were placed in a growth of Elathrium and other shrubby trees surrounded by an almost impenetrable growth of Opuntia cactus. Birds in the fully adult black and white plumage were scarce, and many birds in the brown plumage with white tails were caring for young. Most of the young were in juvenile plumage, though a few still in their natal down could be observed. The smallest of these were from sixteen to eighteen inches in length. The nests were rather crude affairs of sticks placed at heights of from four to twelve feet in the shrubs. The adults, especially those in the fully adult plumage, were much more wary than the Common Boobies. When our party returned to Mayagüez I brought back with me one of the smallest of the downy young, and 
kept it as a laboratory pet for nearly two weeks. It fed greedily upon fish obtained in the market.

Porto Rican specimens now in my collection:

No. 401, male, adult plumage, Desecheo, May 7, 1927.

No. 402, male, immature plumage, Desecheo, May 7, 1927.

No. 409, female, downy young, Desecheo, May 20, 1927.

\section{PHALACROCORAX OLIVACEUS MEXICANUS (Brandt). Mexican Cormorant.}

My only record of a Cormorant from Porto Rico is that of a bird probably of this species observed at Cartagena Lagoon on October 17, 1924, and previously recorded in my "Birds of the Cartagena Lagoon".

9. FREGATA MAGNIFICENS Mathews. Man-0-war Bird. Rabijuneo. Tijerilla. Anunciador.

The Man-o-war Bird is a frequent visitor to all parts of the coast of Porto Rico at all times of the year. It breeds on Desecheo, Cayo Enrique, and possibly some of the other islets off the coast of Porto Rico.

A colony of at least sixty pairs nests on Cayo Enrique. These birds and the Little Blue Herons and Snowy Egrets nest on one end of the key, and the Pelicans and Black-crowned Night Heron's on the other end. The nests of the Man-o-war Birds are placed on the mangroves at heights of from eight to twelve feet. On April 2, 1927 these nests contained one young apiece, ranging in size from newly hatched birds to those nearly ready to leave the nest. One nest still contained an egg, and one nest contained two fairly large young. The adults on their nests permitted me to approach within three or four feet of them before taking flight. On March 22, 1928 about the same conditions were found to 'be true, but no eggs at all were seen. On August 15, 1927 this colony contained many nests with good-sized young, mostly still in their natal down, but a few in juvenile plumage learning to fly were noted. On this visit no eggs nor small young were seen.

During my stay on Desecheo Island from May 7 tol 9, 1927 I found two nesting colonies of Man-o-war Birds in scrubby trees in the lower hills in the interior of the island. The total number of nests in the two colonies was about a hundred and twenty-five. They contained young in various stages of development. Fifteen years before Dr. Wetmore had noted a nesting colony on the highest hill, but 
there was none there at the time of my visit. Large numbers of Man-o-war Birds were robbing the Boobies which were feeding off the coast of Desecheo.

On the main island of Porto Rico the Man-o-war Bird is found mostly along the coast, but occasionally visits fresh water lakes in quest of fish. I have recorded the species at the following localities in Porto Rico: Point Borinquen, Aguada, Rincón, Añasco, Mayagüez, Joyuda, Puerto Real, Boquerón, Faro de Cabo Rojo, Cartagena Lagoon, Parguera, Cayo Enrique, Ensenada, Ponce, Coamo Springs Reservoir, Humacao, Río Piedras, San Juan, Laguna Tortuguera, and Quebradillas.

A stomach from Cayo Enrique contained only fish remains.

Porto Rican specimen now in my collection:

No. 377, female, Cayo Ennrique, April 2, 1927.

10. ARDEA HERODIAS ADOXA Oberholser. West Indian Great Blue Heron. Garzón Ceniza. Yaguasa.

The West Indian Great Blue Heron is found fairly commonly in the coastal region of Porto Rico, but seems to be somewhat more common and generally distributed in the winter months. Possibly a few migrant Great Blue Herons from the north occur at this season, or the birds may retire to remote localities to breed during the summer months.

Usually only one or two birds are seen at a time, but on December 14, 1923 at Anegado Lagoon I noted an assemblage of six, and at Puerto Real on November 3, 1926 I noted five together.

Localities at which I have observed this bird are Añaseo, Mayagüez, Joyuda, Puerto Real, Boquerón, Faro de Cabo Rojo, Parguera, Cartagena Lagoon, Anegado Lagoon, Ensenada, Guayanilla, Tallaboa, Coamo Springs, Ceiba, Toa Baja and Arecibo.

The stomach of a bird collected at Añaseo contairied a fish twelve inches long, and weighing about a pound.

Porto Rican specimen now in my collection:

No. 660, male, Añasco, Nov. 3, 1928.

\section{CASMERODIUS ALBUS EGRETTA (Gmelin). Egret. Garzón Blanco.}

The Egret is found in small numbers in the coastal region of Forto Rico at all times of the year, frequenting both salt and fresh water. It is occasionally found even on flooded meadows. Dr. Wet- 
more found a nest near Mameyes, but I have never observed one. The birds are usually found either singly or in small groups of from two to six. On one occasion (March 23, 1929) I observed ten at the Coamo Springs Reservoir. A pair lived in a mangrove swamp at the edge of the village of Boquerón for some months in 1926 and 1927, and became very tame.

Localities at which I have observed Egrets are: Añasco, Mayagüez, Joyuda, Puerto Real, Cabo Rojo, Boquerón, Faro de Cabo Rojo, Cartagena Lagoon, Cayo Enrique, Anegado Lagoon, Guánica Lagoon, Coamo Springs Reservoir, and Arecibo.

\section{EGRETTA THULA THULA (Molina). Snowy Egret. Garza Blanea.}

The Snowy Egret is found regularly in the coastal region of Porto Rico, but can searcely be said to be common.

Fifteen or twenty pairs nest on Cayo Enrique. The nests are placed in the mangroves at heights of from ten to twelve feet. On April 2, 1927 some nests contained eggs and others newly hatched young. The majority contained three eggs or young, although a few had only two. One nest contained two eggs and one newly hatched young, not yet dry. The young had dark bills and skin and were covered with a white fuzzy down. The adults at this time were wearing their nuptial plumes. They were very wary and took flight long before I got near the nests.

On March 22, 1928 only ten nests were found, two of which contained eggs. The rest contained newly hatched young.

On August 15, 1927 a few nests still had eggs, but most of the birds had young which could scramble around, but were not yet able to fly.

I have found the Snowy Egret at Cartagena Lagoon at all times of the year. My records for localities other than Cartagena Lagoon and Cayo Enrique are but few. A bird was seen on frequent occasions during March and May, 1930 near the mouth of the Guanajibo River at Mayagüez. Three were seen at Joyuda on April 6, 1927, two on November 28, 1929, and two on May 16, 1930. At Parguera I saw eight on February 16, 1929, and at the Coamo Springs Reservoir five on May 26, 1929. Two birds were noted at Arecibo on April 18 and 20, 1930.

Porto Rican specimen now in my collection: No. 5, female; Cartagena Lagoon, Sept. 25, 1926. 
13. HYDRANASSA TRICOLOR RUFICOLLIS (Gosse). Louisiana Heron. Garza de Vientre Blanca.

A few years ago the Louisiana Heron was fairly common at Cartagena Lagoon, but now it is rarely seen there. I never found it common at other localities on the island, and in the past few years it has been rarer than ever. Indeed, I have not seen one elsewhere than at Cartagena Lagoon since December, 1928.

My records other than at Cartagena Lagoon are as follows: Mayagüez, (January, 1922; September 17, 1927; April 14, 19, May 3, and December 13, 1928); Puerto Real (November 3, 1926); 'Boquerón (March 8, 1924, December 18, 1926, and February 14, 1927); Cayo Enrique (April 2 and August 15, 1927; possibly one or two pairs nesting); Anegado Lagoon, (March 4, 1922).

\section{FLORIDA CAERULEA CAERULESCENS (Latham). Southern Little}

Blue Heron. Garza Azul. Garza Blanea. Garza Pinta.

The Little Blue Heron is a very common resident in Porto Rico, mostly near the coast, but occasionally seen in the lower foothills.

A colony of about fifteen pairs nest on Cayo Enrique. Their nests were placed in the same mangroves with those of the Snowy Egrets, about ten feet above the water. The nests were surprisingly small and frail structures of sticks. On April 2, 1927 the nests all contained either two or three eggs or newly hatched young. On August 15, 1927 only two or three nests were found, and on March 22, 1928 I noted that all the birds of this species had moved to a smaller key east of Cayo Enrique which it was impossible to examine closely on this occasion.

The stomach of a bird collected at Aguada contained nine small crabs (85 per cent); 3 Zaitha anura (10 per cent), and a longlegged aquatic spider ( 5 per cent). One collected at Cartagena Lagoon had eaten 4 adults and 1 nymph of Zaitha anura; 1 Pelocoris femoratus; 11 hardback beetless (Dyscinetus picipes), and $6 \mathrm{Hy}$ drophilid larvae.

Localities at which I have observed this bird are: Aguadilla, Coloso, Aguada, Rincón, Añasco, Mayagüez, Hormigueros, Joyuda, Cabo Rojo, Filial Amor, Puerto Real, Boquerón, Faro de Cabo Rojo, San Germán, Sabana Grande, Lajas, Cartagena Lagoon, Maguey Island, Parguera, Cayo Enrique, Anegado Lagoon, Guánica Lagoon, Ensenada, Tallaboa, Ponce, Santa Isabel, Coamo Springs, Coamo Springs Reservoir, Salinas, Yabucoa, Fajardo, Mameyes, Loíza, Río Grande, Bayamón, Toa Baja, Manatí, and Arecibo. 
Porto Rican specimens now in my collection:

No. 264 male, imm., Aguada, Dec. 1, 1926.

No. 368, female, ad., Cartagena Lagoon, Feb. 28, 1927.

15. BUTORIDES VIRESCENS MACULATUS (Boddaert). West Indian Green Heron. Martinete.

The Green Heron is very common in the coastal plain of Porto Rico, and also occurs along stream valleys well up into the hills.

Green Herons usually nest singly, building their crude platforms: of sticks in trees which are often at a considerable distance from water. On April 7, 1929 at Algarrobo I found a nest built on the fronds of a spiny corozo palm, a most inaccessible position. By climbing a nearby tree I could see the two light greenish-blue eggs which the nest contained. During the breeding season the birds hide in the dense foliage of the tree tops, and at frequent intervals, often in the night, emit gulping wullp sounds.

Green Herons were observed by me at the following localities: Aguada, Rincón, Añasco, Mayagïez, Las Marías, Hormigueros, Cabo Rojo, San Germán, Joyuda, Puerto Real, Boquerón, Faro de Cabo Rojo, Cartagena Lagoon, Lajas, Parguera, Maguey Island, Anegado Lagoon, Guánica Lagoon, Ensenada, Peñuelas, Pastillo, Santa Isabel, Coamo Springs, Coamo Springs Reservoir, Guayabal Reservoir, Villalba, Salinas, Patillas, Humacao, Caguas, San Lorenzo, El Río, Mameyes, Martín Peña, Bayamón, Toa Baja, San Vicente, Laguna Tortuguera, Algarrobo, Manatí, Barceloneta, Arecibo, Hatillo, Cidra, Comerío, Naranjito, Adjuntas and Quebradillas.

A stomach from Mameyes contained 7 adult eockroaches and 1 large cockroach nymph.

Porto Rican specimens now in my collection:

No. 6, male, Cartagena Lagoon, Sept. 30, 1924.

No. 7, male, Mameyes, Oct. 12, 1926.

16. NYCTICORAX NYCTICORAX NAEVIUS (Boddaert). Black-crowned Night Heron. Yaboa.

This species is a fairly common bird at Cartagena Lagoon, and there is a small nesting colony on Cayo Enrique. On March 1, 1928 I saw one at Añasco, and on March 15, 1928 a boy brought me an adult male with a nuptial plume which he had just shot by the Yagüez River in Mayagüez.

At Cayo Enrique on April 2, 1927 four nests of this species were found, one with five, two with four, and one with three eggs. On 
March 22, 1928 eight nests were found in this colony. All contained eggs. Sets of two, three, four and five eggs were noted. The nests were placed in the mangroves at heights of about fifteen feet. They were at the opposite end of the key from that on which the Snowy Figrets and Little Blue Herons nested.

Porto Rican specimen now in my collection: No. 597, male adult, Mayagüez, March 15, 1928.

\section{NYCTANASSA VIOLACEA JAMAICENSIS (Linné). Yellow-erowned Night Heron. Yaboa.}

I have not found this species very commonly in Porto Rico, though is is fairly well distributed on the coastal plain.

There is a small nesting colony in an area of dense brush and small trees between Algarrobo and Laguna Tortuguera, at a distance of about a mile and a half from water. In February, $1927 \mathrm{Mr}$. William Burlingame took two fully fledged young nearly ready to fly from this colony. When I visited the colony on March 21, 1927 we succeeded in locating six nests. They were scattered over a considerable area, so it was difficult to find them all. The ground underneath the trees was strewn with white faeces and fragments of large crabs. The nests were placed at heights of from five and a half to ten feet in scrubby jicaco (Chrysobalanus) trees, in a region which was so densely overgrown with brush that the nests were visible only a few feet away. At the time of my visit four of the nests were deserted, the young evidently having just left. Of the other two nests, one contained one large blue egg, and the other three. The eggs in the latter set measured $54 \times 38 ; 54 \times 41$, and $53 \times 38$ millimeters.

At the time of the hurricane of September 13, 1928 the colony was deserted, but a new one was formed in a similar brushy region a quarter of a mile distant. On April 7, $1929 \mathrm{I}$ was able to locate only three nests in the new colony. One was empty. The second was ten feet from the ground in a cupey tree, and contained one egg. The third was five feet from the ground on the branch of a jicaco tree partly blown over by the hurricane. It contained two young at the stage where the feathers were just beginning to break out from the cases, giving them a very bristly appearance. There was also a dead young bird in the nest about half the size of the living young. The young were very savage, making loud screeching sounds, and sticking out their bills at intruders. At times they made low guttural sounds. While we were examining the nest an adult remained perched in a nearby tree watching the proceedings. The iris of the 
young birds was dull yellow. The upper mandible was dusky, tinged with yellowish at the base. The lower mandible was dull yellow tinged with dusky at the tip. The legs were dull yellow with a greenish tinge.

In addition to Algarrobo I have observed this species at Aguada (November 5, 1927); Mayagüez, (sixteen observations); Joyuda (nine observations); Puerto Real (November 3, 1926); Faro de Cabo Rojo (May 14, 1927); Cartagena Lagoon, several records, the most recent being a flock of three adults seen on May 10, 1930 ; Santurce (March 21, 1930), and San Juan (October 14, 1926).

18. BOTAURUS LENTIGINOSUS (Montagu). Bittern. Yaboa.

My only Porto Rican record for the Bittern is that which I have already published (one seen at Cartagena Lagoon on November 30, 1923).

19. IXOBRYCHUS EXILIS EXILIS (Gmelin). Least Bittern. Martinete Chico.

The Least Bittern has become more common at Cartagena Lagoon in recent years. On April 27, 1929 I counted fifteen there. Aside from Cartagena Lagoon I have only two Porto Rican records, one seen at Guánica Lagoon on October 3, 1924 and one at Anegado Lagoon on August 16, 1927.

Porto Rican specimen now in my collection:

No. 732, male, Cartagena Lagoon, April 27, 1929.

20. DENDROCYGNA ARBOREA (Linné). West Indian Tree Duck. Chiriría.

Both this species and $D$. autumnalis are found in Porto Rico, but the majority of the specimens that I have observed closely enough for identification have been autumnalis. On September 22, 1928 I saw at Cartagena Lagoon a flock of nine birds which were certainly arborea.

21. DENDROCYGNA AUTUMNALIS (Linné). Black-bellied Tree Duck. Chiriría.

Although I have no specimens to prove my point, I feel positive that the most common tree duck in Porto Rico is this species. I have on numerous occasions had excellent opportunities for observing this bird under favorable conditions at Cartagena Lagoon. On November 20, 1926 I saw one fly into a dense growth of guinea grass on Ensenada point, from which it was impossible to flush it. 
22. MARECA AMERICANA (Gmelin). Baldpate. Pato Lablanco.

My only records for the Baldpate are those already published in: my "Birds of the Cartagena Lagoon".

\section{DAFILA ACUTA TZITZIHOA (Vieillot). Pintail. Pato Pescuezilargo.}

In addition to the records which I have already published, I can record a male seen at Anegado Lagoon on March 7, 1927, and a male at Cartagena Lagoon on December 10, 1927.

\section{POECILONETTA BAHAMENSIS BAHAMENSIS (Linné). Bahama Duck. Pato Inglés.}

The Bahama Duck is a fairly common resident at Cartagena, Anegado and Guánica Lagoons. Mr. Juan Zalduondo of Fajardo tells me that a few stay all the year at a small brackish lagoon on Piñero. Island near Fajardo, and presented me with a specimen from that locality. On August 18, 1927 I observed one flying low over the city of Mayagüez at dusk.

Porto Rican specimen now in my collection: No. 655, female, Piñero Island, near Fajardo, May 26, 1928.

25. QUERQUEDULA DISCORS (Linné). Blue-winged Teal. Pato Celecel. Pato de la Florida.

The Blue-winged Teal is a common winter resident at Cartagena and Anegado Lagoons. I have not recorded it elsewhere on the island. Fall arrival dates at Cartagena Lagoon are September 6, 1924, September 25, 1926, and September 22, 1928. My latest spring dates are May 2, 1924, April 7, 1928, and April 13, 1929.

26. SPATULA CLYPEATA (Linné). Shoveller. Pato Cuchareta.

At Cartagena Lagoon on December 16, $1928 \mathrm{Mr}$. James Bond and I made careful observations of a female Shoveller in company with four Lesser Scaups. This is my second positive Porto Rican record of the species.

27. MARILA AFFINIS (Eyton). Lesser Scaup Duck. Pato Tureo.

The Lesser Scaup is a common and regular winter resident in Porto Rico. At Cartagena Lagoon it is especially common, and I have counted as many as three hundred in one day (January 12, 1929). I have also recorded the species at Guayabal Reservoir (January 5, 1924 and November 30, 1929); Coamo Springs Reservoir 
(March 18, 1928 and March 24, 1929) ; Boquerón (one on November 6, 1926), and Mayagüez (migrating flock on May 5, 1924, and a crippled female on November 28, 1929).

My first fall records are: September 23, 1924 (Cartagena Lagoon); November 6, 1926 (Boquerón), and November 10, 1928 (Cartagena Lagoon). My latest spring records are: May 16, 1924, May 12, 1928, April 13, 1929 and April 12, 1930, all at Cartagena Lagoon.

\section{ERISMATURA JAMAICENSIS JAMAICENSIS (Gmelin). West Indian Ruddy Duck. Chorizo.}

The Ruddy Duck is an abundant permanent resident on the larger bodies of fresh water. On Cartagena Lagoon it is abundant and nests. I have counted as many as 600 in one day there.

When there is water in Anegado and Guánica Lagoons many are found there. On the Guayabal Reservoir I found 100 on November 30, 1929, and lesser numbers on other dates. When the Coamo Springs Reservoir contains water many Ruddy Ducks oceur there. On February 10, 1929 I found about 300 on the reservoir. On February 22,1930 the reservoir was very nearly dry, but in the tiny pool of water that was left seven females were swimming around. Miss Nina G. Spaulding reports seeing a number at Laguna Rica on April 27, 1930.

Porto Rican specimens now in my collection: No. 10, male, Cartagena Lagoon, July 19, 1925.

No. 11, female, Cartagena Lagoon, March 1, 1924.

No. 357, female, Cartagena Lagoon, January 30, 1927.

No. 358, male, Cartagena Lagoon, January 30, 1927.

\section{CATHARTES AURA AURA (Linné). Southern Turkey Vulture. Aura Tiñosa.}

The Turkey Vulture continues to be restricted to its limited range in the southwestern part of the island. I have found the species from Coamo Springs on the east to Mayagüez on the west, but it is extremely rare at both extremities of its range. My records are as follows: Coamo Springs (one on December 1, 1929); Ponce (numerous records); Tallaboa (fairly common); Peñuelas (December 5, 1926); Guayanilla (several records); Yauco (common); Ensenada (common); Guánica Lagoon (common); Anegado Lagoon (common); Lajas (common); Parguera (common); Sabana Grande (several records); Cartagena Lagoon (common); Boquerón (fairly common); Faro de Cabo Rojo (several records); Monte Grande 
(August 17, 1927); Cabo Rojo, (three records); San Germán (several records); Hormigueros (three records); Mayagïez (one seen on September 28, 1926).

The greatest number I have ever had in sight at one time was twenty-eight near Lajas on January 5, 1930.

30. ACCIPITER STRIATUS VENATOR Wetmore. Porto Rican Sharp-shinned Hawk. Falcón.

This hawk must be considered very scarce at present. In my many trips to the hill country near Maricao I have noted it on only two occasions. On January 1, 1922 I observed one in the hills east of Mayagüez, and on April 16, 1922 one near Montoso Mountain.

\section{BUTEO BOREALIS JAMAICENSIS (Gmelin). West Indian Red-tailed Hawk. Guaraguau. Lechuza.}

The Red-tailed Hawk is a fairly common resident, particularly in the hills. It is usually seen singly or in pairs, but on November 24, 1926 I observed a flock of six adults soaring over Montoso Mountain.

The stomach of a bird collected near Lajas on March 5, 1930 contained the feathers and meat of an Agelaius xanthomus, also a few seeds which were evidently from the Blackbird's stomach.

I have recorded the species at Rincón, Añasco, Mayagüez, Maricao, Montoso Mountain, Consomo, Las Vegas, Las Marías, Boquerón, Cartagena Lagoon, Lajas, Anegado Lagoon, Guánica Lagoon, Coamo Springs, hills between Villalba and Ciales, El Yunque, Vega Alta, Manatí, and the hills between Arecibo and Utuado.

\section{CIRCUS HUDSONIUS (Linné). Marsh Hawk.}

The Marsh Hawk is a rare winter visitant to Porto Rico, where I have observed it only at Cartagena Lagoon. All the examples seen were in the brown plumage. I have recorded it on the following occasions: November 30, December 7, 22 and 27, 1923; December 10, 1927; March 10, 1928; January 12 and March 9, 1929, and February 8, 1930. On each occasion only one bird was seen except on December 22, 1923, when two were noted.

\section{PANDION HALIAETUS CAROLINENSIS (Gmelin). Osprey. Aguila del Mar.}

The Osprey is an uncommon winter visitant to Porto Rico. Early fall records are September 27, 1924 (Cartagena Lagoon); November 3, 1926 (Puerto Real); and November 2, 1929 (Mayagüez). Late spring dates are March 22, 1922 (Boquerón); March 11, 1924 
(Cartagena Lagoon); April 17, 1927 (Mayagüez); April 21, 1928 (Mayagüez), and April 28, 1929 (Joyuda). In addition to the localities mentioned above I have observed the Osprey at El Faro de Cabo. Rojo.

34. FALCO PEREGRINUS ANATUM Bonaparte. Duck Hawk. Falcón.

The Duck Hawk is an uncommon winter visitant to Porto Rico. I have seen it eatch Antillean Gallinules and Ruddy Ducks, and make unsuccessful attempts to capture Little Blue Herons and Common Terns.

Early fall records are: September 30, 1924 (Cartagena Lagoon); December 10, 1927 (Cartagena Lagoon); December 8, 1928 (Cartagena Lagoon), and November 18, 1929 (Joyuda). Late spring dates are: April 1, 1922 (Anegado Lagoon); April 7, 1928 (Cartagena Lagoon), and April 18, 1929 (Boquerón).

All my other records pertain to the places mentioned above except for one bird seen at Hormigueros on December 16, 1928.

\section{FALCO COLUMBARIUS COLUMBARIUS Linné. Pigeon Hawk. Falcón.}

The Pigeon Hawk is a regular but rather uncommon winter resident in Porto Rico, found sometimes in the hills, but more often in the vicinity of lagoons and reservoirs. One or two birds usually frequent Cartagena Lagoon in winter and it is not unusual to see the species at other localities. I have recorded it at Coloso, Mayagüez, San Germán, Sabana Grande, Cartagena Lagoon, Anegado Lagoon, the Coamo Springs Reservoir, a small pond near Maunabo, and at Quebradillas.

Early arrival dates are: October 20, 1924 (Cartagena Lagoon); October 30, 1926 (Cartagena Lagoon), December 1, 1928 (Maunabo), and October 31, 1929 (Mayagüez).

Late Spring dates are April 12, 1922 (Quebradillas); April 25, 1924 (Sabana Grande); April 21, 1928 (Cartagena Lagoon), April 13, 1929 (Cartagena Lagoon), and April 1, 1930 (Mayagüez).

Porto Rican specimen now in my collection: No. 671, female, Cartagena Lagoon, Dec. 16, 1928.

\section{FALCO SPARVERIUS CARIBAEARUM (Gmelin). Antillean Sparrow Hawk. Faleón.}

The Sparrow Hawk is a common resident in Porto Rico. It is particularly abundant in the dry south coastal region, but it is also. locally quite abundant at certain places on the north coast. 
The contents of five stomachs were examined, and the following items were found: Crickets (Gryllus assimilis), 20 per cent; mice, 38 per cent; Anolis lizards, 18 per cent; Anolis eggs, 2 per cent; centipede fragm,ents, 2 per cent; millipedes (Julus caesar), 8 per cent; Long-horned grasshoppers (Neoconocephalus triops), 8 per cent; gravel, 4 per cent (in one stomach).

Near Mayagüez I observed a pair nesting in a hole twenty feet above the ground in a dead cocoanut palm in the early part of May, 1928. When one of my students climbed up to the hole the parent birds made repeated dashes at his face, coming within two or three inches of it.

I find the Sparrow Hawk recorded in my notes from the following localities: Aguadilla, Coloso, Aguada, Rincón, Añasco, Las Marías, Maricao, Mayagüez, Hormigueros, San Germán, Sabana Grande, Boquerón, Faro de Cabo Rojo, Cartagena Lagoon (rare); Lajas, Parguera, Anegado Lagoon, Guánica Lagoon, Guánica, Yauco, Guayanilla, Peñuelas, Tallaboa, Ponce, Santa Isabel, Jayuya, Coamo Springs, Villalba, Juana Díaz, Coamo-Aibonito Road, Aibonito-Cayey Road, Salinas, Guayama, Bayamón, Palo Seco, Vega Baja, Algarrobo, Manatí, Barceloneta, Arecibo, Florida, Hatillo, Camuy and Quebradillas.

Porto Rican specimens now in my collection:

No. 268, female, Las Marías, Dec. 4, 1926.

No. 269, male, Las Marías, Dec. 4, 1926.

No. 615, male, Mayagüez, April 18, 1928.

No. 741, female, Mayagüez, Oct. 29, 1929.

\section{RALLUS LONGIROSTRIS CARIBAEUS Ridgway. Caribbean Clapper Rail. Pollo de Manglar.}

The Clapper Rail is a common inhabitant of the mangrove swamps of Porto Rico, but it is much more often heard than seen. At certain times of the year it is very silent, and may easily be overlooked. It leaves the brackish water mangrove swamps at times of low water, and so may be absent at places where a short time before it was abundant.

By patiently watching small openings in mangrove swamps I obtained three specimens, one of which was retained for my own collection. The stomach contents of these specimens was found to consist entirely of fiddler crabs (Uca pugnax rapax).

I have found Clapper Rails in mangrove swamps at Joyuda, Puerto Real, Boquerón, Faro de Cabo Rojo, Parguera and Fajardo. My specimens were all collected at Boquerón and Puerto Real. 
Porto Rican specimen now in my collection: No. 720, male, Boquerón, April 4, 1929.

38. PORZANA CAROLINA (Linné). Sora. Gallareta Chiquita.

The Sora is a regular and fairly common winter resident at those fresh water lagoons which have sufficient vegetation to provide suitable cover. They are especially common at Cartagena Lagoon, where I have counted as many as 150 in one day (February 11, 1928). I have also observed Soras at Anegado and Guánica Lagoons, and at a small swamp near Mayagüez.

The stomach of a specimen collected was filled with seeds of Compositae. It also contained gravel to the extent of 45 per cent of the contents.

Early fall dates are October 14, 1924 and October 13, 1928. Late spring dates are April 8, 1922; April 18, 1924, March 28, 1927, and April 7, 1928. These migration dates were all obtained at Cartagena Lagoon.

Porto Rican specimen now in my collection:

No. 369, female, Cartagena Lagoon, Feb. 28, 1927.

39. PORZANA FLAVIVENTER HENDERSONI Bartsch. Yellowbellied Rail. Gallareta Chiquita.

The Yellow-bellied Rail is a not uncommon resident at Cartagena Lagoon, although on account of its retiring habits it easily escapes notice. The largest number I have observed on any one day is four. On April 1, 1922 I observed one at Anegado Lagoon. The only two specimens which I have collected are in the Cornell University $\mathrm{Mu}$ seum.

40. IONORNIS MARTINICUS (Linné). Purple Gallinule. Galareta Inglés.

The Purple Gallinule is one of the birds which has increased in abundance during the time that I have been in Porto Rico. Now I should eall it a distinctly common bird at Cartagena Lagoon, where it is not unusual to note as many as forty birds in the course of a morning's field work. I have also recorded the species on two occasions at Mayagïez; and at Guánica Lagoon. A stomach from Cartagena Lagoon contained Persicaria seeds, 88 per cent; and coarse grass, 12 per cent. A stomach from Mayagüez contained nothing but a quantity of vari-colored gravel.

Porto Rican specimens now in my collection: No. 226, male, imm., Cartagena Lagọon, Oct. 30, 1926. 
No. 372, male, ad., Mayagüez, March 5, 1927.

No. 627, female, ad., Mayagüez, May 7, 1927.

\section{GALLINULA CHLOROPUS PORTORICENSIS Danforth. Antillean}

Gallinule. Gallareta. Yagareta.

The Antillean Gallinule is an abundant resident at all the fresh water lagoons in Porto Rico, and is also found at some of the brackish water lagoons and smaller swamps, and in the larger river marshes, and occasionally even in the mangrove swamps. I have found large number's of their nests and eggs at Cartagena and Anegado Lagoons.

I have recorded the species at Aguadilla (one record); Añasco (one record); Mayagüez (common at a small fresh water swamp, and a few may usually be seen near the mouth of the Guanajibo River); Joyuda (in cutover mangrove swamps); Faro de Cabo Rojo (scarce in mangrove swamps); Cartagena Lagoon (abundant); Anegado Lagoon (abundant); Guánica Lagoon (common); Salinas (recorded once in mangrove swamp); Guayabal Reservoir (a few); Coamo Springs Reservoir (common); Toa Alta (one seen at the river); Laguna Tortuguera (a few); Arecibo (numerous records in river marshes and other smaller marshes); Quebradillas (in small marshes along the Guajataca River).

Porto Rican specimens now in my collection:

No. 14, female, Cartagena Lagoon, April 4, 1924.

No. 374, female, Cartagena Lagoon, March 7, 1927.

No. 628, female, Aguadilla, May 7, 1928.

No. 859, male, Mayagüez, May 18, 1930.

\section{FULICA CARIBAEA Ridgway. Caribbean Coot. Gallinazo.}

The Coot is an abundant resident on the larger lagoons and reservoirs of Porto Rico. Their numbers greatly increased during the period following the hurricane of September, 1928. At that time the lagoons were filled, and kept full by the unusually heavy rains which continued for more than a year afterwards. They became so deep and choked with vegetation that egg hunters could not get to the Coot's breeding places either on foot or by boat. This gave the birds a great opportunity to increase. Now it is not at all unusual to see upwards of five thousand Coots in a day at Cartagena Lagoon, and large numbers at other suitable localities.

Coots are abundant at Cartagena Lagoon, and common at Anegado Lagoon, Guánica Lagoon, Guayabal Reservoir, and Coamo 
Springs Reservoir. I have observed a few at Laguna Tortuguera, and one at a small slough near Arecibo.

Porto Rican specimens now in my collection:

No. 15, male, Cartagena Lagoon, Sept. 9, 1924.

No. 16, sex? Cartagena Lagoon, July 19, 1925.

No. 225, male, Cartagena Lagoon, Oct. 30, 1926.

No. 629, male, Cartagena Lagoon, May 12, 1928.

\section{CHARADRIUS NIVOSUS TENUIROSTRIS Lawrence. Cuban Snowy Plover.}

On May 5, 1928 I collected a male at El Faro de Cabo Rojo, on a white sandy salt flat not far from some mangroves. There the white coloration of the bird was very protective. Its testes were large. Its stomach was nearly empty, but contained a few fragments of Staphylinid beetles and some gravel. The species may eventually be found to breed in Porto Rico, as it is known to breed in St. Croix, and it presumably breeds in Haiti.

Porto Rican specimen now in my collection: No. 626, male, Faro de Cabo Rojo, May 5, 1928.

44. CHARADRIUS SEMIPALMATUS Bonaparte. Semipalmated Plover. Putilla.

The Semipalmated Plover is a rather uncommon winter resident along the coasts of Porto Rico. I have collected specimens at Ensenada, and have also seen the species at Mayagüez, Joyuda, Rat Island, Faro de Cabo Rojo, and Salinas.

Early fall dates are: August 16, 1927 (Ensenada); September 10, 1928 (Mayagüez), and September 16, 1929 (Joyuda).

Late spring dates are: April 26, 1924, April 20, 1929 (both at El Faro de Cabo Rojo), and April 5, 1930, at Mayagüez.

These birds are seen most commonly from September to November.

45. PAGOLLA WILSONIA WILSONIA (Ord). Wilson's Plover.

Putilla. Playero.

The Wilson's Plover is a not uncommon resident bird in Porto Rico, found principally along sandy beaches. It is most abundant at El Faro de Cabo Rojo, where it showed all indications of breeding in May, although I have never actually found nests. From 200 to 350 birds can usually be seen at this place. A few can usually be seen at Ensenada, I have several times noted the species at Mayagüez and Joyuda, and I have one record from Boquerón. It is oc- 
casionally found by bodies of fresh water. Of such records I have the following: Cartagena Lagoon (one collected on June 3, 1924 and two seen on October 1, 1927); Anegado Lagoon (five seen on September 29, 1926) ; Guánica Lagoon (fifteen seen on October 2, 1926); Sabana Grande (one seen at the edge of a 'small reservoir on October 6, 1926).

Two stomachs from Boquerón and Ensenada contained nothing but Crustacean remains and a little gravel.

Porto Rican specimens now in my collection: No. 23, male, Faro de Cabo Rojo, April 27, 1924. No. 25, female, Ensenada, Oct. 9, 1926.

46. OXYECHUS VOCIFERUS RUBIDUS Riley. West Indian Killdeer. Putilla. Playero.

The West Indian Killdeer is a permanent resident in Porto Rico, but is apparently much less abundant in the winter months than during the rest of the year. Possibly it is because they spread around more in the winter.

I have never noted migrant Killdeers from North America in Porto Rico, although they are not uncommon in the Virgin Islands. In my recent paper on the birds of the Virgin Islands I have given measurements of my specimens from those islands and from Porto Rico.

I have recorded Killdeers at the following localities: Mayagiiez (Three records, November 7 and 22, 1928, and November 18, 1929); Hormigueros (August 29, 1927 and November 23, 1927); Filial Amor (June 14, 1924); San Germán (May 10, 1928, April 27, 1929 and November 18, 1929); Sabana Grande (October 6, 1926); Boquerón (January 6, 1922, October 17, 1924, May 14, 1927 and September 3, 1928); Faro de Cabo Rojo (April 25, 1924); Cartagena Lagoon (common; breeds, but scarce in winter); Lajas (numerous records at all times of the year); Parguera (October 20, 1929); Anegado Lagoon (common); Guánica Lagoon (common); Ensenada (February 26, 1927, April 24, 1927, October 16, 1927, January 21, 1928, February 22, 1928, September 22, 1928, and November 3, 1928); Yauco (October 9, 1926); Pastillo (April 12, 1927); Santa Isabel (December 1, 1929 and January 26, 1930); Guayabal Reservoir (November 30, 1929); Coamo Springs Reservoir (March 18, 1928, April 29, 1928, March 22, 23 and 24, 1929 ; September 8, 1929); $\mathrm{Hu}-$ macao (January 4, 1924) ; Río Piedras (October 26, 1927); Alga- 
rrobo (March 19 and 21, 1927; June 7 and 8, 1927, and April 20, 1930) ; Arecibo (October 14, 1926, March 9, 20 and 22, 1930, and April 18 and 20, 1930); Quebradillas (March 22, 1930).

A stomach from Arecibo contained entirely animal matter (mostly smooth white caterpillars, and a few beetle fragments). It also had a large amount of coarse sand.

Porto Rican specimens now in my collection: No. 21, male, Cartagena Lagoon, Sept. 23, 1924. No. 22, male, Arecibo, Oct. 14, 1926.

\section{PLUVIALIS DOMINICUS DOMINICUS (Müller). Golden} Plover. Playero.

The Golden Plover is a rare migrant in Porto Rico. On September 29, 1926 I believe I saw a flock of four at Anegado Lagoon, but I was unable to collect any.

\section{SQUATAROLA SQUATAROLA CYNOSURAE Thayer and Bangs. Black-bellied Plover. Playero.}

Formerly the Black-bellied Plover was a very rare visitant in Porto Rico. Until November 3, 1926, when I noted a flock of six birds at Puerto Real, I had never seen the species in the island. Since then it has steadily increased in numbers until now it is a rather common winter resident. I see it regularly at numerous localities along the shore throughout the winter. A stomach was full of fragments of Hippa crabs.

Localities at which I have noted the species are: Mayagüez (a few along the shore throughout the winter); Puerto Real (November 3, 1926); Boquerón (common); Faro de Cabo Rojo (common); Cartagena Lagoon (six on March 28, 1927); Ensenada (common).

Early fall dates are November 3, 1928 (Puerto Real); August 16, 1927 (Ensenada); September 3, 1928 (Boquerón), and October* 4, 1929 (Mayagüez).

Late spring dates are: May 15, 1927, May 5, 1928, and April 20, 1929, (at El Faro de Cabo Rojo), and May 10, 1930 (at Mayagüez).

Porto Rican specimens now in my collection:

No. 663, female, Faro de Cabo Ropo, Sept. 29, 1928.

No. 721, female, Boquerón, March 7, 1929. 


\section{ARENARIA INTERPRES MORINELLA (Linné). Ruddy Turnstone. Playero.}

Ruddy Turnstones are common winter residents along the coasts of Porto Rico. They are in winter plumage most of the time they are with us, but molt into their breeding plumage before leaving in the spring. They are often found in company with Black-bellied Plovers and Sanderlings along the beaches. On April 4, 1927 at Mayagüez I killed thirteen Turnstones and six Sanderlings at one shot. The contents of twelve of the Turnstone stomachs were examined, and found to contain: Fragments of Molluses 50.8 per cent; unidentified animal matter, 7.5 per cent, seeds and pulp of fruits, 41.7 per cent; also sand to the extent of 12.7 per cent of the total contents was found.

Localities at which I have observed Turnstones are: Mayagüez (common); Joyuda (September 16, 23 and December 9, 1929); Boquerón (April 16, 1928 and March 7, 1929); Faro de Cabo Rojo (common); Cayo Enrique (April 2, 1927 and March 22, 1928); Parguera (August 15, 1927); Ensenada (October 9, 1926, August 16, 1927, and September 22, 1928); Guayanilla (November 24, 1927).

Early fall dates are: September 27, 1926 (Mayagüez); August 15, 1927 (Parguera); September 10, 1928 (Mayagüez), and September 16, 1929 (Joyuda).

Late spring dates are: April 27, 1924 (Faro de Cabo Rojo); May 14, 1927 (Faro de Cabo Rojo); May 5, 1928 (Faro de Cabo Rojo); April 24, 1929 (Mayagüez), and May 10, 1930 (Mayagüez).

Porto Rican specimens now in my collection:

No. 378, male, Mayagüez, April 4, 1927.

No. 379, female, Mayagüez, April 4, 1927.

No. 380, female, Mayagüez, April 4, 1927.

No. 381, female, Mayagüez, April 4, 1927.

No. 382, female, Mayagüez, April 4, 1927.

No. 383, male, Mayagüez, April 4, 1927.

No. 384, female, Mayagüez, April 4, 1927.

No. 385, male, Mayagüez, April 4, 1927.

No. 386, female, Mayagüez, April 4, 1927.

No. 387, male, Mayagüez, April 4, 1927.

No. 388, male, Mayagüez, April 4, 1927.

No. 389, female, Mayagüez, April 4, 1927.

No. 390, male, Mayagüez, April 4, 1927. 


\section{CAPELLA DELICATA (Ord). Wilson's Snipe.}

The Wilson's Snipe is a winter resident of somewhat irregular abundance. In the winter of 1926-27 it was exceptionally abundant. On January 29, 1927 I counted 250 at Cartagena Lagoon. Sometimes as many as twenty would flush at once, but they would fly in as many different directions, making no attempt to keep together as a flock. They frequented mostly the grassy areas where there was opportunity for concealment. I have been able to learn no Porto Rican name for the species.

Two stomachs contained nothing but comminuted insects, among which a few fragments of Carabidae were recognized.

I have observed Snipe only at Cartagena, Anegado and Guánica Lagoons, with the exceptions of a bird noted in a canefield at Añasco on December 26, 1923, and one in a small swamp at Mayagüez on February 13, 1924.

Early fall dates are: October 4, 1924, October 30, 1926, December 10, 1927 and October 13, 1928 (all at Cartagena Lagoon).

Late spring dates are: March 22, 1922, April 15, 1924, March 28, 1927, and April 7, 1928 (all at Cartagena Lagoon).

Porto Rican specimens now in my collection:

No. 370, female, Cartagena Lagoon, Feb. 28, 1927.

No. 595, female, Guánica Lagoon, Feb. 22, 1927.

\section{PHAEOPUS HUDSONICUS (Latham). Hudsonian Curlew.}

On February 25, 1928 I noted four on the mudflats in a mangrove swamp at Boquerón, in company with Greater Yellowlegs and Blackbellied Plovers. On September 3, 1928 I saw two at the same place. On September 29, 1928 one was observed flying around the marsh at El Faro de Cabo Rojo.

52. ACTITIS MACDULARIA (Linné). Spotted Sandpiper. Putilla.

The Spotted Sandpiper is a very common winter resident in Porto Rico, found on seabeaches, at lagoons, and along streams, occasionally along the smaller mountain streams and even in damp canefields.

I have recorded the species at Aguada, Añaseo, Mayagüez, Joyuda, Puerto Real, Boquerón, Hormigueros, San Germán, Faro de Cabo Rojo, Cartagena Lagoon, San Germán, Sabana Grande, Parguera, Anegado Lagoon, Guánica Lagoon, Ensenada, Guayabal Reservoir, Coamo Springs, Coamo Springs Reservoir, San Lorenzo, Algarrobo, Manatí, and Quebradillas. 
Early fall dates are: August 13, 1924 (Cartagena Lagoon); August 13, 1927 (Cartagena Lagoon); August 29, 1928 (Mayagüez), and August 27, 1929 (Mayagüez).

Late spring dates are: May 23, 1924 (Cartagena Lagoon); April 18, 1927 (Cartagena Lagoon); May 8, 1928 (Añasco), April 27, 1929 (San Germán), and May 13, 1930 (Mayagüez).

Porto Rican specimen now in my collection: No. 48, male, Cartagena Lagoon, Feb. 19, 1924.

53. TRINGA SOLITARIA SOLITARIA Wilson. Solitary Sandpiper. Putilla.

The Solitary Sandpiper is a tolerably common visitor to Porto Rico in the fall migration, but very rare in the spring. None are found here in the winter. While with us it occurs singly or in small flocks of two or three, mostly along streams, or in flooded meadows, often near the lagoons, but seldom right at the lagoon edges. Sometimes I have seen these birds at small roadside puddles.

I have recorded the species at Añaseo, Mayagüez, Puerto Real, San Germán, Filial Amor, Cabo Rojo, Boquerón, Cartagena Lagoon, Anegado Lagoon, Guánica Lagoon, Guayabal Reservoir, and the Coamo Springs Reservoir.

Early fall dates are: August 30, 1924 (Cartagena Lagoon); September 17, 1926 (Mayagüez); September 24, 1927 (Mayagüez); September 9, 1928 (Mayagüez), and September 7, 1929 (Guayabal Reservoir).

Late fall dates are: October 11, 1924 (Mayagüez); October 2, 1926 (Guánica Lagoon); October 8, 1927 (Cartagena Lagoon); November 2, 1928 (Mayagüez), and October 10, 1929 (Mayagüez).

My only spring dates are of a single bird seen at Anegado Lagoon March 4, 1922, one seen at San Germán March 24, 1928, one collected from a flock of three at Puerto Real on April 16, 1929, and one seen at San Germán April 16, 1929.

Porto Rican specimen now in my collection: No. 731, male, Puerto Real, April 16, 1929.

\section{CATOPTROPHORUS SEMIPALMATUS SEMIPALMATUS (Gmelin). Willet. Playante.}

Formerly I believed that the Boquerón colony of Willets might be resident, but further observations have led me to believe that these birds are strictly migratory in Porto Rico. Every winter a small colony of from twenty to twenty-five Willets winter at some man- 
grove-bordered mudflats near Boquerón, where I took two specimens. now in the Cornell University museum. From five to ten can usually be seen at some mangrove-bordered salt ponds at Puerto Real.

On September 23, 1924 I observed one at Cartagena Lagoon. At El Faro de Cabo Rojo I saw two on April 27, 1924, and one on September 29, 1928.

Early fall dates are: September 23, 1924 (Cartagena Lagoon), and September 29, 1928 (Faro de Cabo Rojo).

Late spring dates are: April 27, 1924 (Faro de Cabo Rojo); April 16, 1928 (Boquerón), and April 18, 1929 (Boquerón).

Porto Rican specimen now in my collection: No. 45, female, Boquerón, Feb.:22, 1924.

\section{TOTANUS FLAVIPES (Gmelin). Lesser Yellowlegs. Putilla. Playante.}

The Lesser Yellowlegs is one of the commonest of the northern shorebirds which visit Porto Rico. It is somewhat more abundant in fall and spring than during the middle of the winter. A few which are probably non-breeding individuals even stay through the summer. They are found most abundantly at the fresh water lagoons, mangrove-bordered mudflats, and saltponds where salt is made by the open-air evaporation of seawater. Sometimes they are found along rivers, and even at small limestone sinkpools and on flooded meadows. I have never found them along sandy seabeaches.

A stomach from Guánica Lagoon contained Hydrophilid larvae: and some unidentified insect fragments.

Localities at which I have recorded these birds are: Aguadilla (October 27, 1929); Añaseo, Mayagüez, Joyuda (October 28, 1928); Cabo Rojo, Puerto Real, Boquerón (common); San Germán; Faro de Cabo Rojo, Cartagena Lagoon (abundant); Anegado Lagoon: (common); Guánica Lagoon (common); Ensenada (common); Guayabal Reservoir, Coamo Springs, Coamo Springs Reservoir, Caguas (December 23, 1929), and Arecibo (common).

Migration dates are rather difficult to obtain on account of the presence of summering individuals. The greater number seem to arrive in August and leave in April or May. October is the month of greatest abundance. The following migration dates represent fairly accurately, I believe, the arrival and departure of migrants. Arrivals: August 13, 1924 and August 13, 1927 (Cartagena Lagoon). Departures: May 14, 1927 (Faro de Cabo Rojo); April 25, 1928 (Cartagena Lagoon), April 17, 1929 (San Germán), anđ May 10, 1930 (Cartagena Lagoon). 
Porto Rican specimens now in my collection:

No. 43, female, Cartagena Lagoon, Sept. 17, 1924.

No. 44, female, Guánica Lagoon, Oct. 2, 1926.

No. 359, male, Boquerón, Feb. 14, 1927.

\section{TOTANOS MELANOLEUCUS (Gmelin). Greater Yellowlegs, Putilla. Playero, Playante.}

Like the preceding species, this is a winter visitant from North America, but a few individuals stay through the summer, at least at Cartagena Lagoon. It is, however, much less common than the Lesser Yellowlegs, though some years it could hardly be called rare. It is found most commonly at the larger fresh water swamps, and at the mangrove-bordered salt water swamps. A stomach from Guánica Lagoon contained four large aquatic Coleopterous larvae.

I have recorded Greater Yellowlegs at Mayagüez (November 26, 1929); Joyuda; Puerto Real; Boquerón (common); Faro de Cabo Rojo, Sabana Grande (September 13, 1926); Cartagena Lagoon (common); Anegado Lagoon (common); Guánica Lagoon (common); Ensenada (October 9, 1926 and August 16, 1927); Coamo Springs Reservoir (March 18, 1928), and Arecibo (October 14, 1926, and March 21 and 22, 1930).

Migration dates, so far as distinguishable from summering birds, are: Arrival: August 16, 1927 (Ensenada). Departures: April 22, 1922 and April 23, 1927 (Cartagena Lagoon), and March 24, 1928 (Boquerón).

Porto Rican specimen now in my collection: No. 39, Cartagena Lagoon, June 10, 1924.

\section{PISOBIA MINUTILLA (Vieillot). Least Sandpiper. Putilla.}

The Least Sandpiper is an abundant migrant, and uncommon winter resident in Porto Rico. The last migrants in the spring searcely leave before the first return migrants from the north arrive. I have observed the species in every month of the year except June. While with us Least Sandpipers are sometimes found on sandy beaches, but are more abundant at the edges of lagoons and at mangrove-bordered mudflats.

A stomach from Cartagena Lagoon and another from Guánica Lagoon contained 85 per cent Hydrophilid larvae; and fragments of insects (including Coleoptera), 15 per cent. Also, in one of them, gravel to the extent of 75 per cent of the stomach contents was found.

Localities at which I have recorded Least Sandpipers are: Aguada, 
Mayagüez, Joyuda, Sabana Grande, Boquerón, Faro de Cabo Rojo, Cartagena Lagoon, Anegado Lagoon, Guánica Lagoon, Ensenada, Coamo Springs Reservoir, Salinas, and Arecibo.

Migration dates, all at Cartagena Lagoon, are: Arrival, July 5, 1924. Late Spring dates: May 30, 1924, April 23, 1927, April 25, 1928, April 27, 1929, and May 10, 1930.

Porto Rican specimens now in my collection:

No. 34, female, Cartagena Lagoon, March 25, 1924.

No. 36, female, Cartagena Lagoon, Sept. 25, 1926.

58. PISOBIA MELANOTOS (Vieillot). Pectoral Sandpiper. Putilla.

The Pectoral Sandpiper is an abundant fall migrant, and a few are found in the spring migration. It occurs most frequently in damp grassy areas near lagoons, but I have found it at the edges of small pools, along rivers, on salt water mudflats, and even in dry fields far from water.

The stomachs of three birds collected at Anegado Lagoon September 29, 1926 were full of Geometrid caterpillars. They also contained 18 per cent of gravel. A stomach from Cartagena Lagoon collected September 17, 1927 contained seven cranefly larvae, also a little undetermined animal matter and one piece of quartz gravel.

Localities at which I have observed the species are: Mayagüez, Cabo Rojo, Faro de Cabo Rojo, Cartagena Lagoon, Lajas, Anegado Lagoon, Guánica Lagoon, Coamo Springs and Arecibo.

Early fall dates are August 13, 1924 and August 13, 1927 (at Cartagena Lagoon).

Late fall dates are: October 20, 1924 (Cartagena Lagoon); November 3, 1926 (Cabo Rojo); October 8, 1927 (Lajas), and October 13, 1928 (Cartagena Lagoon).

My only spring records are April 1, 1922 at Anegado Lagoon and April 27, 1924 at El Faro de Cabo Rojo.

Porto Rican specimens now in my collection:

No. 29, female, Anegado Lagoon, Sept. 29, 1926.

No. 30, female, Anegado Lagoon, Sept. 29, 1926.

No. 31, female, Anegado Lagoon, Sept. 29, 1926.

No. 550, male, Cartagena Lagoon, Sept. 17, 1927.

59. PISOBIA FUSCICOLLIS (Vieillot). White-rumped Sandpiper. Putilla.

This species is a rather uncommon fall migrant in Porto Rico. I have recorded it at Boquerón, Cartagena Lagoon, Guánica Lagoon, 
the saltponds at Ensenada, and at the Coamo Springs Reservoir. Two stomachs from Cartagena Lagoon contained comminuted insects and a large amount of gravel.

Early fall dates are August 26, 1924 and August 13, 1927 (at Cartagena Lagoon), and September 8, 1929 (Coamo Springs Reservoir).

Late fall dates are October 20, 1924 (Cartagena Lagoon); October 9, 1926 (Ensenada); and October 8, 1927 (Cartagena Lagoon).

Porto Rican specimens now in my collection:

No. 32, male, Cartagena Lagoon, Aug. 26, 1924.

No. 33, female, Guánica Lagoon, Oct. 2, 1926.

No. 548, male, Cartagena Lagoon, Sept. 17, 1927.

60. MICROPALAMA HIMANTOPUS (Bonaparte). Stilt Sandpiper. Putilla.

The Stilt Sandpiper is a tolerably common fall migrant in Porto Rico, where I have observed it only at Cartagena and Guánica Lagoons. A stomach from Guánica Lagoon was mostly filled with sand, but contained a few insect fragments. One from Cartagena Lagoon was filled with comminuted animal material.

Early fall dates are: August 20, 1924 and September 17, 1927 at Cartagena Lagoon. Late fall dates are: September 27, 1924 (Cartagena Lagoon); October 2, 1926 (Guánica Lagoon); and October 1, 1927 (Cartagena Lagoon).

Porto Rican specimens now in my collection:

No. 26, female, Cartagena Lagoon, Aug. 20, 1924.

No. 27, male, Cartagena Iaagoon, Aug. 20, 1924.

No. 28, female?, Guánica Lagoon, Oct. 2, 1926.

No. 549, male, Cartagena Lagoon, Sept. 17, 1927.

61. EREUNETES PUSILLUS (Linné). Semipalmated sandpiper. Putilla.

The Semipalmated Sandpiper is a very abundant fall migrant. In the spring it is rather uncommon. It frequents mostly the borders of fresh water lagoons, salt water mudflats, and saltponds, but it is often found at small roadside pools, and even in moist canefields and grassy fields.

On October 9, 1926 I observed a flock of about fifteen swimming on the saltponds at Ensenada where salt is made by the openair evaporation of seawater. At that place the water was about a foot deep. On being scared up the birds flew to land, but soon returned to swimming. They were apparently feeding upon the brine shrimps 
(larvae of Ephydridae) which abounded there. The stomach of one collected was filled with them.

Localities at which I have observed the species are: Hormigueros, Joyuda, Boquerón, Faro de Cabo Rojo, Cartagena Lagoon, Anegado Lagoon, Guánica Lagoon, Ensenada and Coamo Springs Reservoir.

Early fall dates are: August 13, 1924 and August 13, 1927 (Cartagena Lagoon).

Late fall dates are: October 20, 1924 (Cartagena Lagoon); October 9, 1926 (Ensenada); October 8, 1927 (Cartagena Lagoon); September 29, 1928 (Faro de Cabo Rojo), and October 12, 1929 (Joyuda).

My earliest positive spring date is April 21, 1928 at Cartagena Lagoon, when three were collected for identification.

Late spring dates are May 15, 1927 (Faro de Cabo Rojo), and May 12, 1928 (Cartagena Lagoon).

Porto Rican specimens now in my collection:

No. 37, female, Cartagena Lageon, Aug. 20, 1924.

No. 38, female, Ensenada, Oct. 9, 1926.

62. EREUNETES MAURI Cabanis. Western Sandpiper. Putilla.

My only Porto Rican record continues to be that of a female collected at Cartagena Lagoon on August 26, 1924.

63. CROCETHIA ALBA (Pallas). Sanderling. Putilla.

The Sanderling is a bird which was formerly rare in Porto Rico, but in recent years it has come to be a common winter resident. It is apparently just about as common all through the winter as it is in migrations. It is almost exclusively a bird of the sandbeaches, where it is almost invariably found associated with Ruddy Turnstones, and often with Black-bellied Plovers. It is in its white winter plumage almost all the time it it with us, but occasionally when it first arrives in the fall and just before it leaves in the spring a few molting birds are seen.

The contents of seven stomachs were examined. The food was found to consist exclusively of animal material, of which Crustaceans formed 69.4 per cent, Molluses 16.4 per cent, and sandworms 4.1 per cent. The stomachs also contained gravel to the extent of 7 per cent of their contents.

I have recorded Sanderlings at Aguada, Mayagüez (common), Joyuda, Boquerón, Faro de Cabo Rojo, Ensenada (common), and Salinas. 
Early fall dates are October 9, 1926 (Ensenada); September 21, 1928 and September 11, 1929 (Mayagüez).

Late spring dates are April 4, 1927, April 30, 1929, and May 3, 1930, at Mayagüez.

Porto Rican specimens now in my collection:

No. 47, male, Ensenada, Oct. 9, 1926.

No. 391, female, Mayagüez (Correccional Point), April 4, 1927.

No. 392, male, Mayagüez (Correccional Point), April 4, 1927.

No. 393, female, Mayagüez (Correccional Point), April 4, 1927.

No. 394, female, Mayagüez (Correccional Point), April 4, 1927.

No. 395, male, Mayagüez, (Correccional Point), April 4, 1927.

No. 396, female, Mayagüez (Correccional Point), April 4, 1927.

64. HIMANTOPUS MEXICANUS (Müller). Black-necked Stilt. Viuda.

The Stilt is a common breeding bird in Porto Rico, but it is not found here in winter. At Boquerón and El Faro de Cabo Rojo a few are found in the mangrove swamps, and a few at a brackish water pond at Ensenada. Many breed at Cartagena, Anegado and Guánica Lagoons. I have once recorded the species at Puerto Real. Two stomachs were full of comminuted insects and a little gravel. Hemiptera, including, water boatmen, figured largely among the insects. Carabid beetles and damselflies were also recognized.

Early spring dates are March 4, 1922 (Anegado Lagoon); March 11, 1924 (Cartagena Lagoon); March 7, 1927 (Anegado Lagoon), and March 9, 1929 (Cartagena Lagoon).

Late fall dates are: October 7, 1924 (Cartagena Lagoon); November 3, 1926 (Puerto Real), and October 27, 1928 (Boquerón). They stay later in the mangrove swamps than at the lagoons.

Porto Rican specimens now in my collection:

No. 49, male, Cartagena Lagoon, May 2, 1924.

No. 50, female, Guánica Lagoon, Oct. 2, 1926.

No. 373, female, Anegado Lagoon, March 7, 1927.

65. LARUS ATRICILLA Linné. Laughing Gull. Gaviota.

The Laughing Gull is a common summer visitor to the coasts of Porto Rico, but I doubt if it breeds here. I have recorded the species at Point Borinquen, Aguada, Rincón, Mayagüez, Joyuda, Faro de Cabo Rojo, Cartagena Lagoon (2 records); Cayo Enrique, Ponce and San Juan. It is a common bird in Mayagüez Harbor in the summer months. A few were seen on Desecheo Island on May 7 and 8,1927 , but they were apparently not breeding. 
Early spring dates are: March 6, 1924, April 14, 1927, March 31, 1929, and April 15, 1930 (all at Mayagüez).

Late fall dates are: September 13, 1926 (Mayagïiez); September 9, 1927 (Mayagüez); September 29, 1928 (one in winter plumage at El Faro de Cabo Rojo); and October 16, 1929 (Joyuda).

66. GELOCHELIDON NILOTICA ARANEA (Wilson). Gull-billed Tern. Gaviota.

The Gull-billed Tern is a rather rare summer visitor to Porto Rico, but apparently does not breed here. A few frequented Cartagena Lagoon from May 20 to September 3, 1924 and I took a female on July 9. Three were noted at the same place on August 13, 1927, and on September 3, 1928 I collected a female over some mudflats at Boquerón.

Porto Rican specimen now in my collection:

No. 632, female, Boquerón, Sept: 3, 1928.

67. STERNA HIRUNDO HIRUNDO (Linné). Common Tern. Gaviota.

This tern is a common summer visitor to the coasts of Porto Rico, but I have found no evidence of its breeding here.

On September 14, 1928 an injured bird of this species in winter plumage, was found in the hurricane wreckage on the principal street of Mayagüez. It bore band No. 676305 on its leg, showing that it had been banded as a young bird on July 5, 1928 at Chatham, Massachusetts.

Localities at which I have observed Common Terns are: Aguada, Mayagüez, Joyuda, Rat Island, Faro de Cabo Rojo, Ponce, San Juan and Arecibo.

Early spring dates are: January 29, 1927; March 14, 1928; March 1, 1929, and January 24, 1930, all at Mayagüez.

Late fall dates are: October 7, 1926 (Mayagüez); September 20, 1927 (Rat Island); November 16, 1928 (Joyuda); and November18, 1929 (Joyuda).

Porto Rican specimen now in my collection:

No. 51, female, imm., Mayagüez, Oct. 7, 1926.

68. STERNA DOUGALLII DOUGALLII Montagu. Roseate Tern. Gaviota.

On May 9, 1927 I observed a pair two miles west of Rincón Point. On August 15, 1927 about 150 were feeding between Parguera and Cayo Enrique. On September 2, 1928 a large flock of terns, mostly of this species, was seen feeding a few hundred feet offshore nearAguada. 
69. STERNA ANAETHETA RECOGNITA Mathews. Bridled Tern. Gaviota.

On May 7 and 8, 1927 on Desecheo Island, after dark about fifteen of these birds came in to sleep under a small overhanging cave near: our campsite. They made a great deal of noise, and flew back and: forth in the dark before going to sleep. One of our party shot two $o: \vec{i}$ them by firing at them when they got between him and the moon. Both were males with enlarged testes. None were seen in the daytime.

Porto Rican specimens now in my collection: No. 405, male, Desecheo, May 8, 1927.

No. 406, male, Desecheo, May 8, 1927.

\section{STERNA FUSCATA FUSCATA Linné. Sooty Tern. Gaviota Oscura.}

The Sooty Tern is occasionally seen off the coasts of Porto Rico. A few were seen off the north coast east of Arecibo on June 13, 1927. Off Aguada a few were seen in a mixed flock of terns on September 2, 1928. On October 6, 1929 at the same place of flock of about 500 terns, mostly if not all of this species, were feeding about a quarter of a mile offshore, accompanied by about 150 Boobies.

71 STERNULA ALBIFRONS ANTILLARUM (Lesson). Least Tern. Gaviota.

There is a breeding colony of about twenty-five pairs of Least Terns at El Faro de Cabo Rojo, which is the only: place on the island at which I have observed this species. They are not found here exeept during the breeding season. The earliest spring dates I have are April 27, 1924 and April 20, 1929. They begin nesting early in May. On May 14, 1927 a number of their nests were located on some sandy islets in the extensive salt flat lagoon near the lighthouse. At that time egg-laying was taking place. Some of the nests contained two eggs, and others only one, and I collected a female with an egg ready to be laid. The nests were simply small depressions in the sand, in one case with a little debris piled around it. The eggs were light buff colored, so spotted with chocolate as to be difficult to observe against the sand. When the colony was first approached a number of birds arose and scolded with great vigor, but they soon tired of it and left the vicinity. When I visited the colony on May 5, '1928 about fifty birds were in evidence, but no eggs had been laid as yet, although a female collected contained an egg nearly ready to lay. The stomachs of the birds collected contained small silvery fishes. 
Porto Rican specimens now in my collection:

No. 407, female, Faro de Cabo Rojo, May 14, 1927.

No. 408, male, Faro de Cabo Rojo, May 15, 1927.

No. 624, male, Faro de Cabo Rojo, May 5, 1928.

No. 625, female, Faro de Cabo Rojo, May 5, 1928.

72. THALASSEUS MAXIMUS MAXIMUS (Boddaert). Royal Tern. Gaviota.

The Royal Tern is a tolerably common winter resident on the coasts of Porto Rico, and is the only member of its family that is found here regularly at that season. It is possible that a few may spend the summer here, but I have no July nor August records.

One stomach was filled with small fish bones, and another with Crustacean remains.

I have recorded Royal Terns at Aguada, Joyuda, Boquerón, El Faro de Cabo Rojo, and San Juan.

Early fall dates are: September 22, 1926 (Boquerón); September 29, 1928 (Faro de Cabo Rojo); and September 2, 1929 (Aguada).

Late spring dates are: June 13, 1927 (San Juan), and April 16, 1928 (Boquerón).

Porto Rican specimens now in my collection:

No. 236, female, Boquerón, Nov. 6, 1926.

No. 665, female, Faro de Cabo Rojo, Sept. 29, 1928.

73. THALASSEUS SANDVICENSIS ACUFLAVIDUS (Cabot). Cabot's Tern. Gaviota.

Gabot's Tern is a rare winter visitor to Porto Rico. My only records are of an individual noted from December 4 to 22, 1923 at Cartagena Lagoon.

74. CHLIDONIAS NIGRA SURINAMENSIS (Gmelin). Black Tern. Gaviota Prieta. Gaviota Ceniza. Pitirre de Agua.

The Black Tern is a fairly common fall migrant at Cartagena Lagoon, and on September 22, 1928 I observed six in winter plumage skimming over a shallow pond of brackish water back of the beach at Ensenada. My earliest record at Cartagena Lagoon is August 20, 1924, and my latest records are October 7, 1924 and September 25, 1926.

Porto Rican specimen now in my collection: No. 52, female, Cartagena Lagoon, Sept. 3, 1924. 
75. ANOUS STOLIDUS STOLIDUS (Linné). Noddy. Cervero.

At Desecheo Island on May 8, 1927 one individual was noted on the north shore, and about 200 on the east shore, perched on ledges in the cliffs whence they were loath to fly. Many were krilding crude nests of sticks and debris on the ledges. Many of these were examined, but none in which eggs had been deposited was noted. The following day about twenty birds were noted fishing and floating on the water about two miles east of the island. My only record for the main island of Porto Rico' is of a few birds noted near Cayo Enrique on August 15, 1927.

Porto Rican specimen now in my collection: No. 404, female, Desecheo Island, May 8, 1927.

76. COLUMBA LEUCOCEPHALA Linné. White-crowned Pigeon. Paloma Cabeza Blanca.

At present the White-crowned Pigeon must be considered a rare bird in Porto Rico. Being a lover of the lowland forests it has been largely deprived of its favorite habitat and forced to seek other more favorable regions. Quite a number still breed in the scrubby sand dune forest in the vicinity of Algarrobo and Laguna Tortuguera, but I know of no other place in the island where they can be seen regularly. However, I have the following scattered records from other places: Aguada (four seen on December 1, 1926); San Sebastián (eight seen on April 11, 1927) ; Añasco (four seen on January 24,.1927); Mayagüez (one seen on October 20, 1926); Monte Grande (one seen on August 17, 1927); Faro de Cabo Rojo (Pair seen on April 27, 1924), and El Yunque (ten seen at elevations of 2500-3000 feet on February 21, 1927).

Porto Rican specimen now in my collection: No. 398, male, San Sebastián, April 11, 1927.

77. COLUMBA SQUAMOSA Bonneterre. Scaled Pigeon. Paloma Turea.

The only place on the main island where I have found Scaled Pigeons is on El Yunque. There they were abundant in the dense forests from 1700 feet almost to the summit, frequenting especially the growths of palms. The species has been reported to me from the region of Maricao and Las Marías. On Desecheo Island one of my students reported to me seeing eight or ten in the hilly interior of the island on May 7, 1927. 
78. COLUMBA INORNATA EXSUL (Ridgway). Porto Rican Blue Pigeon.

On November 13, 1926 I flushed two Blue Pigeons from a Royal Palm tree in a coffee plantation in the hills near Añasco. On taking flight they made a loud clapping noise. The species is very nearly extinct in Porto Rico.

79. ZENAIDA AURITA ZENAIDA (Bonaparte). Zenaida Dove. Tórtola.

The Zenaida Dove is fairly common and widely distributed in Porto Rico. The birds are usually very wary and difficult to approach. They occur singly or in small flocks. I have found their nests in trees on the semiarid hills of southern Porto Rico, also in the cattails at Cartagena Lagoon. They frequently come to this and other lagoons and streams to drink water and to feed.

Localities at which I have observed Zenaida Doves are: Point Borinquen, San Sebastián, Aguada, Rineón, Mayagüez (common in the vicinity of mangrove swamps by the Caño Corazón and Guanajibo River), Mayagüez-Maricao Road, Joyuda, Boquerón, Faro de Cabo Rojo, Filial Amor, San Germán, Cartagena Lagoon, Lajas, Anegado Lagoon, Guánica Lagoon, Ensenada, Yauco, Guayanilla, Juana Díaz, Coamo Springs, Mameyes, San Lorenzo, Las Piedras, Cidra, Comerío, Algarrobo, Arecibo-Utuado Road, Hatillo, Quebradillas, and Isabela.

A few were observed in the interior of Desecheo Island on May 7 and 8, 1927.

Porto Rican specimen now in my collection: No. 711, male, Boquerón, Jan. 19, 1929.

80. CHAEMEPELIA PASSERINA TROCHILA Bonaparte. Porto Rican Ground Dove. Rolita. Rola. Tortolita.

The Ground Dove is an abundant bird in the lowlands of Porto Rico, especially in the drier regions. It is occasionally found at fairly high elevations in the hills. This was the bird that apparently suffered most in the San Felipe hurricane of September 12, 1928. For nearly a year after that seareely any were seen, but then they rapidly began to reestablish themselves, and at the present writing (1930) are quite common again, although not yet back to pre-hurricane abundance.

On one occasion (April 7, 1928) at Cartagena Lagoon I saw a flock of 150 birds, but usually they occur in pairs or smaller flocks.

The food of the Ground Dove consists practically entirely of small seeds, largely of grasses. In several stomachs that were examined nothing but small seeds were found. 
The bills of specimens collected in Porto Rico were dull rose at the base with dusky tips.

I have found but five oceupied nests of this species in Porto Rico. A list of the nests follows. (1) Tinaja Hill, south of Cartagena Lagoon, May 28, 1922. The nest was on the ground under the shelter of a small rock and contained two fresh eggs. (2) El Faro de Cabo Rojo, May 15, 1927, built in a small shrub. It contained two young. (3) Mayagüez, May 2, 1928, placed at a height of seven feet in a tree. It contained two eggs. (4) Mayagüez, May 3, 1928, nine feet above the ground on the horizontal branch of a tree, and containing two eggs. The incubating bird did not flush until approached closely. (5) Faro de Cabo Rojo, April 20, 1929, on the ground; really no nest at all, but just some dry grass pressed down to form a slight depression on which the two eggs were laid.

At night Ground Doves roost in thick-foliaged trees.

Localities at which I have observed Ground Doves are: Point Borinquen, Aguadilla, Coloso, Aguada, Rineón, Añaseo, Mayagüez, Mayagüez-Maricao Road, Joyuda, Hormigueros, Cabo Rojo, Puerto Real, Guanaquilla, Boquerón, Faro de Cabo Rojo, Monte Grande, Filial Amor, San Germán, Sabana Grande, Cartagena Lagoon, Lajas, Parguera, Anegado Lagoon, Guánica Lagoon, Ensenada, Yauco, Guayanilla, Peñuelas, Tallaboa, Ponce, Pastillo, Santa Isabel, Juana Díaz, Coamo Springs, Salinas, Jayuya, Maunabo, Yabucoa, Mameyes, Canóvanas, Río Piedras, Martín Peña, San Juan, San Vicente, Vega Alta, Algarrobo, Vega Baja, Guaynabo, Arecibo, Arecibo-Utuado Road, Quebradillas and Isabela.

Porto Rican specimens now in my collection:

No. 55, male, Guánica Lagoon, Oct. 3, 1924.

No. 56, male, Boquerón, Sept. 22, 1926.

No. 57, male, south of Lajas, Sept. 23, 1926.

No. 273, male, Point Borinquen, Dec. 8, 1926.

\section{OREOPELEIA MONTANA (Linné). Ruddy Quail Dove. Perdiz.}

The Ruddy Quail Dove is now found almost exclusively in coffee plantations, where it is far from common. Apparently the mongoose keeps it from reproducing rapidly. In the forests on El Yunque at elevations below 2000 feet it is somewhat more abundant. I have found it in the coffee plantations near Añasco, Mayagüez and Maricao. A stomach was nearly filled with orange seeds. It also contained a few small black seeds and some white quartz sand. 
Porto Rican specimen now in my collection: No. 727, male, Mayagüez, March 18, 1929.

82. OREOPELEIA CHRYSIA (Bonaparte). Key West Quail Dove. Perdiz.

On January 20, 1924 in a coffee plantation in the hills between Mayagüez and Añasco I flushed a bird of this species.

\section{AMAZONA VITTATA VITTATA (Boddaert). Porto Rican Parrot. Cotorra.}

The Parrot is now a very rare and locally distributed bird. So far as I can ascertain it is now found only in the forests of the Sierra Luquillo, where I have not been successful in finding any. One of my students, Mr. Juan Zalduondo, tells me that on June 19, 1927 he observed seven parrots in scattered groups near the base of El Yunque, and that he shot and ate two of them. On December 29, 1927 he visited the Finca La Rosario in the Sierra Luquillo, and found about fifty parrots, of which he shot eight. He preserved one of them as a birdskin and presented it to me.

Porto Rican specimen now in my collection: No. 592, male, Finca La Rosario, Dec. 29, 1927.

\section{COCCYZUS AMERICANUS AMERICANUS (Linné). Yellow-billed Cuckoo. Pájaro Bobo.}

This Cuckoo is a decidedly rare bird in Porto Rico, though it is possible that it breeds here. I have just two records, one collected in a ceiba tree near Cartagena Lagoon on August 13, 1927, and one flushed in some brushy growth at Ensenada on September 22, 1928. The stomach of the bird collected contained twenty-one Lepidopterous larvae, which were identified by Dr. W. T. M. Forbes as Noctuidae of the Catocaline-Erebid series.

Porto Rican specimen now in my collection: No. 546, male, Cartagena Lagoon, Aug. 13, 1927.

85. COCCYZUS MINOR TERES Peters. Mangrove Cuckoo. Pájaro Bobo.

The Mangrove Cuckoo is a widely distributed but rather uncommon bird in Porto Rico. I have found it most commonly in coffee plantations, although I have records from mangrove swamps, dry brushy areas, dense thickets and shade trees.

My records are from the following localities: Añasco, Mayagïez, Maricao, Las Marías, Puerto Real, Cartagena Lagoon, Yauco, Coamo Springs, Aguas Buenas, Vega Alta, Algarrobo, and Quebradillas. 
The condition of the gonads of a male collected at Mayagüez on June 24, 1924 and of a female at Añasco, April 22, 1928 indicated that they were breeding at about that time. The stomach of the latter bird contained a cricket, six katydid eggs, and some miscellaneous insect fragments.

Porto Rican specimen now in my collection: No. 617, female, Añasco, April 22, 1928.

86. SAUROTHERA VIEILLOTI Bonaparte. Porto Rican Lizard Cuckoo. Pájaro Bobo Mayor.

The Lizard Cuckoo is very common in the dense coffee woods near Maricao, and actually abundant in the brush covered limestone hills east of Vega Alta. It is seen fairly frequently in the coffee woods near Mayagüez and Añasco, and I have seen it near Las Marías, along the Arecibo-Utuado Road, in the forests of El Yunque, and occasionally in the dry brushy regions at Ensenada and near Tallaboa.

Five stomachs contained Anolis lizards (in 3 stomachs) 50.6 per cent; lizard eggs, 2 per cent; a large green Sphingid caterpillar, 6.6 per cent; other caterpillars, 16.1 per cent; a very large walking stick, 14 per cent; centipedes, 6 per cent; a Cerambycid beetle (Solenoptera thomae), 2.8 per cent; and miscellaneous animal matter, 1.9 per cent. A piece of white quartz gravel was found in one stomach.

Porto Rican specimens now in my collection:

No. 258, male, Montoso Mt., Nov. 24, 1926.

No. 356, male, Añasco, Jan. 24, 1927.

No. 594, male, Maricao, Feb. 4, 1928.

No. 742, female, Vega Alta, March 9, 1930.

\section{CROTOPHAGA ANI (Linné). Ani. Judío.}

The Ani is a common resident bird in Porto Rico. It is found in most parts of the island where there is open country, although I have several times observed it in the woods.

On January 4, 1930 near. Mayagüez a flock of eight birds was flying around from tree to tree in some coffee woods. At frequent intervals one of the birds would vibrate its outspread wings and emit a medley of squeaks and squawks, making as much noise as a large flock of grackles. The whole flock seemed very much excited. Apparently these actions had something to do with mating, although I did not see any actual mating take place. 
In February 1922 a nest placed high in a large tree at Mayagüez was occupied by a flock of Anis. It was of bulky construction, tapering almost to a point at the bottom. The position of the nest was so inaccesible that I was unable to make any detailed observations of the nesting activities. I have already reported a nest which I observed under construction at Cartagena Lagoon in December, 1923.

Anis have been observed by me at Point Borinquen, Aguadilla, San Sebastián, Rincón, Añasco, Mayagüez, Hormigueros, Joyuda, Cabo Rojo, Puerto Real, Boquerón, Faro de Cabo Rojo, Filial Amor, Monte Grande, San Germán, Sabana Grande, Cartagena Lagoon, Lajas, Parguera, Anegado Lagoon, Guánica Lagoon, Ensenada, Yauco, Guayanilla, Tallaboa, Peñuelas, Jayuya, Ponce, Pastillo, Santa Isabel, Guayabal Reservoir, Villalba, Juana Díaz, Coamo, Coamo Springs, Salinas, Cidra, Juncos, San Lorenzo, Las Piedras, El Yunque (at low altitudes), Martín Peña, Dorado, Toa Baja, Algarrobo, Manatí, Barceloneta, Garrochales, Arecibo, Arecibo-Utuado Road, Camuy and Quebradillas.

Porto Rican specimens now in my collection:

No. 61, male, Cartagena Lagoon, Sept. 30, 1924.

No. 227, female, Cartagena Lagoon, Oct. 30, 1926.

No. 618, female, Mayagüez, April 24, 1928.

88. GYMNASIO NUDIPES NUDIPES (Daudin), Bare-legged Owl. Múearo.

The Bare-legged Owl is a common resident in the wooded regions of Porto Rico, where its trilling song, somewhat higher pitched and more rapidly uttered than that of the Sereech Owl, is a conspicuous sound of the night. This song is heard at all times of the year, although somewhat less frequently in the winter than during the spring and summer months. This little owl is strictly nocturnal in its habits. I have never come across one of them in the daytime, nor have I ever heard its song before nightfall. On a few occasions I have heard the birds continue singing for about half an hour after sunrise. They are more vociferous on moonlight than on dark nights. Sometimes at night owls can be seen flying across the road in front of automobile headlights, with a straight, direct flight, evidently in pursuit of some insect. I have found it impossible to jack these owls with a flashlight.

A stomach from Mayagüez was filled with insects, among which a large grasshopper and a weevil (Diaprepes abbreviatus) were recognized. 
I have seen or heard múcaros at the following localities: Añaseo (common); Mayagüez (common); Maricao (common); Montoso Mountain (common); Hormigueros, San Germán, Cartagena Lagoon (reported), Coamo Spring's, Cidra, El Yunque, Algarrobo, AreciboUtuado Road, Adjuntas, Utuado-Ponce Road. They are probably common in all the wooded hilly parts of the interior of the island.

Porto Rican specimens now in my collection:

No. 713, male, Mayagüez, Jan. 27, 1929.

No. 714, female, Mayagüez, Oct. 3, 1924.

89. ASIO DOMINGUENSIS PORTORICENSIS Ridgway. Porto Rican

Short-eared Owl. Pájaro Cuco. Múcaro Real. Múcaro de Sabana.

On September 29, 1926 while I was observing birds at the edge of Anegado Lagoon one of these owls flew down from a hill and alighted in some marsh grass growing in water about two feet deep. I flushed it two or three times afterwards, and succeeded in photographing it before collecting it. Each time it flew a crowd of small birds, mainly Holoquiscalus, gathered around it to scold. On shooting the ow] I merely winged it, and brought it back to Mayagüez alive. At first it was very fierce, and attacked me with bill and claws, but it soon weakened and died. Its stomach contained small bird feathers, some white, others black at the base and reddish brown at the tip.

Mr. Wm. Burlingame reports seeing and almost eatching a shorteared owl at Algarrobo on May 9, 1930.

Porto Rican specimen now in my collection: No. 63, male, Anegado Lagoon, Sept. 29, 1926.

90. ANTROSTOMUS CAROLINENSIS (Gmelin). Chuck-will's-widow.

Although I have never found this species in Porto Rico, one of my students reports seeing it on several occasions in winter at Lares. He described the bird and its habits very accurately, and picked it out immediately from among the other Caprimulgidae in the colored plates I have at hand, so I feel no hesitation in listing these records.

\section{CHORDEILES MINOR GUNDLACHII Lawrence. Cuban Nighthawk.}

The Cuban Nighthawk is a rare summer visitor in Porto Rico, and probably breeds. I have never succeeded in collecting a specimen, so some of my records may refer to the Bahaman Nighthawk.

My records are as follows: Mayagüez (one on May 2, 1928, and a flock of 10 on May 20, 1930); San Germán (one on April 27, 1929); Faro de Cabo Rojo (several on May 14, 1927); Cartagena 
Lagoon (one on each of the following dates: May 27, June 7 and June 28, 1924) ; Ensenada (one on August 16, 1927); Guánica (two on September 6, 1929); Algarrobo (one heard just before dawn on February 22, 1928, and five seen by Miss N. G. Spaulding on April 24, 1930).

These birds are usually seen flying around on cloudy afternoons, or after heavy afternoon showers.

\section{NEPHOECETES NIGER NIGER (Gmelin). Antillean Black Swift. Golondrina.}

The Black Swift is seen only in summer in Porto Rico, where it probably breeds. My records run from the last of March to the last of July. Usually only small flocks are seen, often in company with swallows. On one occasion on a showery afternoon (May 13, 1928) about 125 swifts were flying over a river and bordering coffee woods near Mayagüez. On another occasion (March 29, 1924) forty were flying over the then-dry Anegado Lagoon. On two occasions (April 30, 1928 at Mayagüez and April 27, 1929 at San Germán) I have seen as many as twenty together, but these large assemblages are unusual. When these swifts fly low a soft "tchip, tchip" call note may be heard.

I have the following records for the species: Mayagüez (Mareh 31, 1922 and several successive dates; May 24, 28, 31, July 12 and 28, 1924; May 10, 11, 23, 24, 26 and 29, 1927; April 4, 23, 30, May 13 and 17, 1928; April 21, 25, May 9 and 19, 1929, and May 20, 1930); San Germán (April 27, 1929); Filial Amor (May 16, 1924) ; Guanaquilla (June 28, 1924), and Anegado Lagoon (March 29, 1924).

93. CHLOROSTILBON MAUGAEUS (Audebert and Vieillot). Porto Rican

Emerald. Fork-tailed Hummingbird. Zumbadoreito.

The Fork-tailed Hummingbird is a fairly common resident bird in Porto Rico, found in many types of localities, but nevertheless somewhat local in its distribution and irregular in its times of occurrence at any one particular locality. At one time or another it is found everywhere from the high rain forests of El Yunque to the driest regions on the south coast, and even occasionally in the mangrove swamps.

It breeds quite commonly in the brushy, sandy region near Algarrobo, where Miss Nina G. Spaulding has found their nests, and on November 17, 1929 observed parents feeding young just out of the nest. 
On November 8, 1926 I observed and photographed a nest in a coffee plantation near Maricao. The nest was placed seventeen inches above the ground in a coffee seedling in a seedbed. It was attached to the vertical stem. The nest was made of banana and other plant fibers, and was lined with fine plant down. Four small pieces of lichen were stuck on the outside. It contained one young with a little fuzzy down on its back and its eyes not yet open. It also contained fragments of a broken egg. When a friend of mine saw the nest on October 30 it contained two eggs. On my visit, as previously, the female was very tame and permitted herself to be stroked on the back without leaving the nest, merely spreading her wings on being stroked. In fact I had to actually lift her off the nest in order to see the young, and then she would return within a few seconds. Once I picked her up to examine the colors of her soft parts, and then let her go. She flew away, but returned to the nest within a minute. The foreman of the coffee pickers, who were at work near the nest, said that if a nest is found when it has eggs one can dig the plant up by the roots, and carry plant and nest into a house, and that the female will stay on the nest all the time, and continue to incubate the eggs in the house. The iris of the female was very dark brown, and the bill, legs and feet black. The skin of the young was black, sparsely covered with reddish brown down. Its bill was dull orange.

On April 25, 1927 at Consomo I discovered another nest with young. It was attached to a slender drooping twig of a tree, near the bases of the terminal leaves, fifteen feet above a brook, in a quite inaccessible position.

These diminutive hummers are very pugnacious, and do not hesitate to attack birds very much larger than themselves, even Sparrow Hawks.

I have observed the species at the following localities: Aguadilla, Añasco, Mayagüez, Maricao, Montoso Mountain (up to the very summit), Consomo, Las Marías, San Sebastián, Joyuda, Cabo Rojo, Puerto Real, Boquerón, Faro de Cabo Rojo, Cartagena Lagoon, Anegado Lagoon, Ensenada, Yauco, Guayanilla, Tallaboa, Coamo Springs, Guayama-Cayey Road, El Yunque (up to 3,000 feet), and Algarrobo.

Porto Rican specimens now in my collection:

No. 65, male, Mayagüez, June 30, 1924.

No. 235, male, Boquerón, Nov. 6, 1926.

No. 376, female, Consomo, March 11, 1927.

No. 608, male, Mayagüez, April 14, 1928. 
94. ANTHRACOTHORAX VIRIDIS (Audebert and Vieillot). Green Mango. Zumbador.

The Green Mango is a common resident in Porto Rico. It is particularly abundant in the interior coffee woods, but at certain places and seasons it is not at all uncommon on the coast. Its presence at the coast seems to depend upon the blossoming of certain flowers. At Puerto Real, for example, it fairly swarms in November when some vines growing in a brushy region back of the beach are in blossom, but in December, when these blossoms are gone, not a hummer is to be seen in this region.

Early in the morning, while the woods are still dripping with the dews of the night before, these hummers love to perch on some bare twig to sun themselves and preen their feathers.

Localities at which I have observed Green Mangos are: Añasco, Mayagüez, Consomo, Puerto Real, Monte Grande, Cartagena Lagoon and Yauco.

A stomach from Mayagüez contained two spiders (45 per cent) and comminuted insects (55 per cent). One from Puerto Real contained a yellow flower spider.

Porto Rican specimens now in my collection:

No. 222, female, Mayagüez-Maricao Road, Oct. 23, 1926.

No. 361, male, Mayagüez, Feb. 18, 1927.

No. 607, male, Mayagüez, April 14, 1928.

No. 610, female, Mayagüez, April 15, 1928.

No. 662, male, Puerto Real, Nov. 6, 1928.

No. 716, female, Monte Grande, Feb. 7, 1929.

95. ANTHRACOTHORAX AURULENTUS (Audebert and Vieillot). Porto Rican Mango. Zumbador.

The Porto Rican Mango is the common hummer of the coastal regions of Porto Rico. It is found to some extent in the hills, but not at very high altitudes nor in the dense woods.

On April 1, 1922 at Anegado Lagoon I found a newly completed nest which I have already described. On May 14, 1927 at El Faro de Cabo Rojo I discovered another nest. It was a compact affair made of white, cottony plant fibers, and placed in a mangrove tree at a height of six feet from the ground at a point where some twigs gave it side support. It contained two newly hatched young and some pieces of broken eggshell. The female was very solicitous for the welfare of her offspring, and whirred almost into my face while I 
was examining them. On March 30, 1929 at Cartagena Lagoon I captured a young bird just out of the nest, but as yet unable to fly.

At Puerto Real early in November these birds, in company with the Green Mangos, fairly swarm at the blossom of an unidentified vine. As with most hummers, the local abundance of the species at different times of the year depends upon the blossoming period of certain favored plants.

Two stomachs contained nothing but small insects and spiders.

Localities at which I have observed the species are: Añasco, Mayagüez, Mayagüez-Maricao Road, Joyuda, Puerto Real, Sabana Grande, Boquerón, Faro de Cabo Rojo, Cartagena Lagoon, Parguera, Cayo Enrique, Anegado Lagoon, Ensenada, Yauco, Juana Díaz, Coamo Springs, Fajardo, Río Piedras, Algarrobo, Camuy and Quebradillas.

Porto Rican specimens now in my collection:

No. 71, male, Guánica Lagoon, Oct. 3, 1924.

No. 72, male, Guánica Lagoon, Oct. 2, 1926.

No. 243, male, imm. Añaseo, Nov. 13, 1926.

No. 619, male, imm. Joyuda, April 27, 1928.

No. 631, male, Anegado Lagoon, Sept. 1, 1928.

No. 735, male, Cartagena Lagoon, March 9, 1929.

96. STREPTOCERYLE ALCYON ALCYON (Linné). Belted Kingfisher. Pájaro del Rey. Martín Peseador.

The Kingfisher is a common winter resident in Porto Rico. It is most abundant along the coast, but is sometimes found along streams well into the mountainous interior of the island. It is also found at the fresh water lagoons, but not so commonly as along the coast.

Two birds collected at Mayagüez had eaten nothing but fish, while two small gray crabs were found in the stomach of one collected at Joyuda.

Early fall dates are: October 14, 1921 (San Juan); September 23, 1924 (Cartagena Lagoon); September 22, 1926 (Boquerón); September 25, 1927 (Mayagüez); September 29, 1928 (Faro de Cabo Rojo), and September 20, 1929 (Joyuda).

Late spring dates are: April 11, 1922 (Quebradillas); April 18, 1927 (Mayagüez); April 21, 1928 (Mayagüez); May 1, 1929 (Mayagüez), and April 24, 1930 (Joyuda).

Localities at which I have observed the species are: Aguada, Rincón, Añasco, Mayagüez, Maricao, mountains five miles east of Maricao, Consomo, Cabo Rojo, San Germán, Joyuda, Rat Island, Puerto 
Real, Boquerón, Faro de Cabo Rojo, Cartagena Lagoon, Anegado Lagoon, Ensenada, Peñuelas, Tallaboa, Ponce, Adjuntas, Utuado, Naranjito, Salinas, Coamo, Coamo Springs, Central Aguirre, Maunabo, Playa de Naguabo, Santurce, San Juan, Algarrobo, Arecibo, and Quebradillas.

Porto Rican specimens now in my collection:

No. 84, male, Mayagüez, Oct. 7, 1926.

No. 260, male, imm., Joyuda, Nov. 27, 1926.

97. TODUS MEXICANUS Lesson. Porto Rican Tody. San Pedrito. Medio Peso.

The Tody is a common resident in the wooded regions of Porto Rico, and is even found to some extent in the brushy areas in the dry south coastal region. It is most abundant in the coffee woods. In regions where the Tody is common one frequently sees its nesting holes dug in the clay banks bordering streams or in other places.

On October 12, 1928 at Consomo about ten Todies were feasting upon a swarm of mayflies which had just emerged along a small stream.

- The contents of five stomachs were examined, and 99.4 per cent animal matter and 0.6 per cent vegetable matter was found. The latter consisted of a seed in one stomach. Spiders formed 14.4 per cent; earwigs 1.6 per cent; Coleoptera 31.4 per cent (including bark beetles 12 per cent, and weevils 1.6 per cent); Lepidopterous larvae 19.7 per cent, and winged ants 1.4 per cent. The rest of the animal matter consisted of comminuted insects. One bird had eaten a feather, probably its own.

The ordinary note is a rather harsh check, slightly suggestive of that of the Ruby-crowned Kinglet, but a little longer drawn out and less abrupt.

Localities at which I have observed Todies are: San Sebastián, Aguada, Añasco, Mayagüez, Las Marías, Consomo, Maricao, Montoso Mountain, San Germán, Monte Grande, Cartagena Lagoon, Parguera, Anegado Lagoon, Yauco, Yauco-Lares Road, Adjuntas, Utuado, Jayuya, Orocovis, Corozal-Orocovis Road, Cidra, Guayanilla, Tallaboa, Villalba-Ciales Road, Coamo Springs, Guayama, El Yunque, Aguas Buenas, Vega Alta and Quebradillas.

Porto Rican specimens now in my collection:

No. 81, female, Mayagüez, Dec. 23, 1923.

No. 82, female, Yauco, Oct. 6, 1926.

No. 83, female, Mayagüez, Oct. 20, 1926. 
No. 257, male? Montoso Mountain, Nov. 24, 1926.

No. 613, male, Las Marías, April 6, 1928.

No. 719, female, Coamo Springs, Feb. 10, 1929.

98. MELANERPES PORTORICENSIS (Daudin). Porto Rican

Woodpecker. Carpintero.

The Woodpecker is common wherever there is sufficient cover. The female has the red on the under surface of the body much less extensive than the male. The nesting holes are excavated in cocoanut palms, almendros or other trees, usually at heights of twenty feet or more above the ground. The birds begin occupying the nest holes in January, but probably do not deposit eggs until February. On March 4, 1927 a boy climbed up to a nest hole high in a cocoanut palm, cut the hole open with a machete, and captured the incubating bird on the nest, which contained four white eggs. He presented the bird and the eggs to me. On dissection the bird proved to be a male.

Four stomachs were examined, and found to contain 65 per cent vegetable and 35 per cent animal matter. The former consisted of fruits (jobo, quenep, and some small unidentified fruits). The animal matter was composed entirely of insects, among which cockroaches 12.5 per cent, Coleopterous larvae 10 per cent, and weevils 2.5 per cent were recognized.

Localities at which I have observed Porto Rican Woodpeckers are: San Sebastián, Aguada, Añasco, Mayagüez (common), Las Marías (common), Consomo (common), Maricao (common), Montoso Mountain (common), Joyuda (rare), Puerto Real (common in cocoanut palms), south of Boquerón, San Germán, Monte Grande, Parguera (rare), Anegado Lagoon (rare), Ensenada (rare), Yauco, VillalbaCiales Road (common), Orocovis, Coamo Springs (common), San Lorenzo, El Yunque, Vega Alta, Algarrobo, Arecibo-Utuado Road, and Quebradillas.

Porto Rican specimens now in my collection:

No. 90, male, Mayagüez, Sept. 25, 1924.

No. 91, male, Mayagüez, Oct. 16, 1926.

No. 371, male, Mayagüez, March 4, 1927.

No. 737, female, Mayagüez, March 16, 1929.

No. 738, female, Maricao, March 16, 1929.

99. TYRANNUS DOMINICENSIS DOMINICENSIS (Gmelin). Gray Kingbird. Pitirre.

The Gray Kingbird is an abundant resident in Porto Rico, particularly in the coastal regions. It appears to be somewhat more 
abundant in the winter than in the summer, also to have a greater tendency to congregate, although it can never be said to form large flocks. I believe it is possible that some of the birds which breed in Florida and Cuba may winter here.

The Gray Kingbird is one of the first birds to awaken in the morning, and on moonlight nights I have heard it begin calling two hours. before dawn.

The stomach of a bird collected contained three medium-sized brown cockroaches. In the field I observed a Pitirre capture a large red winged wasp (Pepsis rubra). It carefully removed the wasp's wings before swallowing it.

Localities at which I have observed this species are: Point Borinquen, Aguadilla, San Sebastián, Coloso, Aguada, Rincón, Añaseo, Mayagüez, Joyuda, Puerto Real, Hormigueros, Cabo Rojo, Guanaquilla, San Germán, Sabana Grande, Monte Grande, Filial Amor, Boquerón, Faro de Cabo Rojo, Cartagena Lagoon, Lajas, Parguera, Anegado Lagoon, Guánica Lagoon, Ensenada, Yauco, Guayanilla, Tallaboa, Peñuelas, Ponce, Jayuya, Fortuna, Pastillo, Santa Isạbel, Juana Díaz, Guayabal Reservoir, Villalba, Coamo, Coamo Springs, Coamo Springs Reservoir, Patillas, Humacao, Naguabo, Fajardo, San Lorenzo, Las Piedras, Aibonito, El Yunque (rare above 1,000 feet), Mameyes, Canóvanas, Loíza, Trujillo Alto, Río Grande, Carolina, Río Piedras, Martín Peña, Bayamón, Caguas, Cidra, Aguas Buenas, Gurabo, Juncos, Vega Alta, Vega Baja, Algarrobo, Manatí, Arecibo, Arecibo-Utuado Road, Utuado, Ciales, Camuy, Quebradillas and Isabela.

Porto Rican specimens now in my collection:

No. 92, female, Cartagena Lagoon, Sept. 23, 1924.

No. 265, male, Aguada, Dec. 1, 1926.

100. TOLMARCHUS TAYLORI (Sclater). Porto Rican Petchary. Clérigo.

The Petchary is a common resident bird in Porto Rico, where it is most abundant in the coffee woods, but it is found at times in almost any region where there is cover, even in the mangrove swamps.

Three stomachs contained nothing but insects. One contained a large Sphinx moth and a weevil (Diaprepes abbreviatus). Another had eaten a male carpenter bee (Xylocopa brasilianorum). The third stomach contained two wasps (Polistes crinitus) and a small black Sphecid wasp.

I have observed Petcharies at San Sebastián, Aguada, Rincón,. 
Añasco, Mayagüez, Maricao, Montoso Mountain, Consomo, Joyuda, Cabo Rojo, Puerto Real, Boquerón, Cartagena Lagoon, Parguera, Anegado Lagoon, Yauco, Tallaboa, Peñuelas, Guayabal Reservoir, Santa Isabel, Coamo Springs, Aibonito, San Lorenzo, Las Piedras, Cidra, El Yunque, Mameyes, Algarrobo, Manatí, Ciales-Jayuya Road. Utuado, Quebradillas and Isabela.

Porto Rican specimens now in my collection:

No. 95, female, Mameyes, Oct. 12, 1926.

No. 223, female, Mayagüez-Maricao Road, Oct. 23, 1926.

No. 231, male, Mayagüez, Nov. 1, 1926.

No. 354, male, Mayagüez, Jan. 17, 1927.

\section{MYIARCHUS ANTILLARUM (Bryant). Porto Rican Flycatcher.} Jüi.

This flycatcher was fairly common when I first arrived on the island, but in the past few years it has become a decidedly rare bird, whether from scarcity of nesting sites or from other unknown causes it would be difficult to state. It is found chiefly in wooded or brushy areas where it can keep under cover. It is occasionally found in mangrove swamps. It captures its prey of insects on the wing.

Four stomachs contained 53.3 per cent of animal matter and 46.7 per cent of vegetable matter. The latter consisted of small fruits, including Cordia sp. Turning to the animal matter, Coleoptera formed 25.1 per cent, and included Lachnopus curvipes, other weevils, and Buprestid beetles, Chrysobothris wolcotti. Damselflies and Lepidopterous larvae each formed 12.5 per cent.

Localities at which I have observed this species are: Aguada, Añasco, Mayagüez, Maricao, Joyuda, Cartagena Lagoon, Parguera, Anegado Lagoon, Guánica Lagoon, Yauco, Ponce, Villalba-Ciales Road, Juana Díaz, Coamo Springs, El Yunque (up to 3,000 feet), and Algarrobo.

Porto Rican specimens now in my collection:

No. 103, male, Yauco, Oct. 6, 1926.

No. 104, male, Mayagüez, Oct. 20, 1926.

No. 251, female, Hills south of Anegado Lagoon, Nov. 20, 1926.

102. BLACICUS BLANCOI Cabanis. Porto Rican Pewee. Bobito.

The Pewee is another bird which, like the Myiarchus, has become very scarce in Porto Rico in recent years. The decrease of neither can scarcely be attributed to the hurricane of 1928 , as it was very noticeable before that time. The Pewee is primarily a bird of the 
coffee woods, and it is confined to central and western Porto Rico. My easternmost record is Coamo Springs, and I never saw it during my frequent visits to that place until September 8, 1929. Since that time a pair has frequented a wooded ravine back of the hotel.

The contents of four stomachs was found to be exclusively insects. Among them the following items were recognized: An earwig (Phaulex albipes), two Cicadas (Proarno hilaris) in one stomach, a tree hopper, and three weevils (Chalcodermus pupillatus). Coleoptera and Diptera figured very largely in the stomach contents.

I used to find the Pewee common at Añasco, Mayagüez, Las Marías, Consomo and Maricao. Other localities at which I have found it more rarely are Joyuda and Puerto Real (in the mangrove swamps); Faro de Cabo Rojo, Ensenada and south of Anegado Lagoon (on dry brushy or sparsely wooded hills), and at Coamo Springs.

Porto Rican specimens now in my collection:

No. 106, female, Mayagüez, June 24, 1924.

No. 224, female, Mayagüez-Maricao Road, Oct. 23, 1926.

No. 248, female, Consomo, Nov. 17, 1926.

No. 267, male, Mayagüez, Dec. 3, 1926.

103. RIPARIA RIPARIA RIPARIA (Linné). Bank Swallow. Golondrina.

The Bank Swallow is tolerably common in Porto Rico in the spring migration, frequenting the vicinity of water. I have observed from five to fifty at Cartagena Lagoon on April 8, 1922, from February 19 to April 30, 1924, on March 28, 1927, from February 11 to April 25, 1928, and on February 8, March 6, and May 10, 1930. At Anegado Lagoon I observed about thirty on March 4 and April 1, 1922, and a few at Laguna Tortuguera on March 20 and 22, 1927. I have in my collection a mummified specimen which I found dead, impaled on a barbed wire fence, at Cartagena Lagoon.

Porto Rican specimen now in my collection:

No. 605, sex?, mummy, Cartagena Lagoon, April 7, 1928.

104. HIRUNDO ERYTHROGASTER Boddaert. Barn Swallow. Golondrina.

The Barn Swallow is fairly common in migration, and a rare and irregular winter resident in Porto Rico. Until this past winter I never observed any at that season. From November 29 to December 1, 1929 I noted about fifteen frequenting the vicinity of Coamo 
Springs Reservoir, and on January 10, 1930 about ten were skimming over a dry parched field near Yauco.

While with us the Barn Swallow is usually found at the lagoons, but occasionally along rivers, or even over dry fields. The only localities at which I have observed the species are Mayagüez, San Germán, Cartagena Lagoon, Anegado Lagoon, Yauco, and Coamo Springs Reservoir.

Early fall dates are: August 26, 1924 (Cartagena Lagoon), and September 11, 1927 (Mayagüez).

Late fall records are: September 30, 1924 (Cartagena Lagoon); October 9, 1926 (San Germán), and September 22, 1928 (Cartagena Lagoon).

Early spring dates are: March 1, 1924, March 28, 1927, and February 8, 1930 (all at Cartagena Lagoon).

Late spring dates are May 14, 1922, May 23, 1924, April 25, 1928, April 13, 1929, and May 10, 1930, (all at Cartagena Lagoon).

\section{PETROCHELIDON FULVA POECILOMA (Gosse). Jamaican Cliff} Swallow. Golondrina de Cuevas.

The Cliff Swallow is an abundant resident. During the breeding season it is restricted to those regions where it finds suitable nesting. sites, but during the rest of the year wanders over the entire island. The nesting season is from April to June.

A stomach from El Faro de Cabo Rojo was filled with insects, of which nymphs of aquatic Hemiptera (Zaitha anura) formed 80 per cent, and Tenebrionid beetles 20 per cent.

In the fall and winter these swallows often appear in large flocks in localities distant from their nesting sites.

Localities at which I have observed this species are: Coloso, Aguada, Rincón, Añaseo, Mayagüez, Consomo, Maricao, Hormigueros, San Germán, Filial Amor, Cabo Rojo, Sabana Grande, Boquerón, Faro de Cabo Rojo, Cartagena Lagoon, Lajas, Anegado Lagoon, Guánica Lagoon, Ensenada, Yauco, Tallaboa, Ponce, Juana Díaz, Coamo, Coamo Springs, Ceiba, Aibonito, Río Piedras, Santurce, San Juan, Bayamón, Vega Alta, Algarrobo, Manatí, Arecibo, Utuado and Quebradillas.

Porto Rican specimens now in my collection:

No. 107, female, Cartagena Lagoon, Aug. 13, 1924.

No. 108, male, Cartagena Lagoon, Aug. 13, 1924.

No. 664, male, Faro de Cabo Rojo, Sept. 29, 1928. 


\section{PROGNE DOMINICENSIS (Gmelin). Caribbean Martin. Golondrina de Iglesias.}

The Martin is a common summer resident and breeder in Porto Rico, but is absent during the winter. It nests in ventilating holes and belfries of buildings, and occasionally in holes in trees. It is most abundant in the towns, but is occasionally found nesting far from towns.

I have observed Caribbean Martins at Aguada, Rincón, Añasco, Mayagüez, Maricao, Joyuda, Puerto Real, Cabo Rojo, San Germán, Sabana Grande, Boquerón, Cartagena Lagoon, Yauco, Ponce, Santa Isabel, Fajardo, Santuree, San Juan, Barranquitas, Laguna Rica (near Algarrobo), Quebradillas and Isabela.

Early spring dates are January 6, 1922 at Boquerón, and February 19, 1924, January 23, 1927, January 24, 1928, January 14, 1929, and January 27, 1930 at Mayagüez.

Late fall dates are: September 9, 1924 (Mayagüez); September 25, 1926 (Cartagena Lagoon); September 11, 1927 (Mayagüez); September 14, 1928 (Mayagüez), and September 6, 1929 (San Germán).

107. CORVUS LEUCOGNAPHALUS Daudin. Porto Rican Crow. Cuervo.

On February 21, 1927 I heard a Crow at an elevation of 3,200 feet on El Yunque. That is my only experience with the species in life in this island. However, on December 28, 1927 at Finca La Rosario in the Sierra Luquillo one of my students, Mr. Juan Zalduondo, saw over a hundred Crows, and collected one for me.

Porto Rican specimen now in my collection: No. 591, female, Finca La Rosario, Dec. 28, 1927.

\section{MIMUS POLYGLOTTOS ORPHEUS (Linné). Jamaican Mockingbird.} Ruiseñor.

The Mockingbird is an abundant resident in Porto Rico. It prefers open lowland country, and is especially abundant in the dry south coastal region.

Mockingbirds breed most commonly in the spring, but on November 20, 1926 at Ensenada I collected a female containing an egg nearly ready to be deposited. They sing to some extent throughout the year, but most commonly from January to September.

Two stomachs contained exclusively small fruits, Jicaco and others.

Localities at which I have observed Mockingbirds are: Point Borinquen, Aguadilla, San Sebastián, Aguadilla, Coloso, Aguada, Rin- 
cón, Añasco, Mayagüez, Joyuda, Puerto Real, Cabo Rojo, Hormigueros, San Germán, Filial Amor, Monte Grande, Guanaquilla, Boquerón, Faro de Cabo Rojo, Cartagena Lagoon, Lajas, Parguera, Anegado Lagoon, Guánica Iagoon, Ensenada, Yauco, Guayanilla, Tallaboa, Peñuelas, Ponce, Pastillo, Juana Díaz, Guayabal Reservoir, Villalba, Santa Isabel, Coamo Springs, Salinas, Guayama, Humacao, Las Piedras, Juncos, Mameyes, El Yunque (up to 1,700 feet), Canóvanas, Río Piedras, Bayamón, Vega Alta, San Vicente, Algarrobo, Laguna Tortuguera, Manatí, Garrochales, Arecibo, Morovis, AreciboUtuado Road, Camuy, Quebradillas and Isabela.

Porto Rican specimens now in my collection :

No. 122, female, Cartagena Lagoon, Sept. 30, 1924.

No. 253, female, Ensenada, Nov. 20, 1926.

109. MARGAROPS FUSCATUS FUSCATUS (Vieillot). Pearly Eyed Thrasher. Zorzal Pardo. Pío-Juan.

This Thrasher is a species which is becoming more abundant and more generally distributed in Porto Rico. Formerly it was primarily a bird of the dry brush-covered hills of the south coast. In recent years it has become common at the west end of the island, in the regions of Rincón, Mayagüez and Joyuda, and I see it much more frequently than formerly in other parts of the island.

Its song is very similar, but somewhat inferior to that of the Thrush. It is not quite so loud nor so rich, though it has a greater variety of notes, and the songs of the two birds are at times distinguishable only with difficulty. The song of Margarops may be heard to some extent at any season of the year, but most frequently from January to September.

Margarops is the only Passerine bird found on Desecheo Island, where I found it rather searce at the time of my visit in May, 1927. In Porto Rico I have noted it at San Sebastián, Aguada, Rincón, Añasco, Mayagüez, Joyuda, Las Marías, Cabo Rojo, Monte Grande (common), Faro de Cabo Rojo, Cartagena Lagoon (rare), hills south of Guánica Lagoon, Yauco, Coamo Springs, Guayama, Naguabo, El Yunque (up to 2,000 feet), Trujillo Alto, Arecibo and Quebradillas.

On April 26, 1928 I discovered a nest at Joyuda. It was a rather bulky affair built mainly of dry leaves, and placed in the small branches near the top of a tree twenty feet above the ground. The well fledged young flew out of the nest when I approached it too closely.

Porto Rican specimen now in my collection: No. 124, female, Monte Grande, Oct. 6, 1926. 
110. MIMOCICHLA ARDOSIACEA PORTORICENSIS (Bryant). Porto Rican Thrush. Zorzal. Zorzal de Patas Coloradas.

The Thrush is a common resident in Porto Rico, very common in the coffee woods, and fairly common in other regions where there is sufficient cover.

On September 10, 1927 at Mayagüez I found a young bird scarcely out of the nest, and on May 2, 1928, also at Mayagüez, some boys brought me two well fledged young nearly ready to fly which they said they had taken from a nest high up in a tree. On March 30, 1924 I found a nest with eggs (which I have already described), and I have observed birds carrying nesting material early in February. A female collected at San Sebastián on April 11, 1927 contained eggs ready for the shell.

The song of the Porto Rican Thrush is quite similar to that of the American Robin, but is less varied and the tones are not so rich. On the morning after the hurricane of September 13, 1928 the only bird that could be heard amid the scene of desolation was a Thrush singing from the leafless trees at daybreak before the hurricane winds had entirely ceased.

A stomach contained a small fruit, and another a Long-horned Grasshopper (Neoconocephalus triops), and some tree frog bones (Eleutherodactylus sp).

Localities at which I have observed Porto Rican Thrushes are: Aguadilla, San Sebastián, Añasco, Mayagüez, Maricao, Consomo, Las Marías, Joyuda, Puerto Real, Cabo Rojo, San Germán, Monte Grande, Guanaquilla, Cartagena Lagoon, Lajas, Lares-Yauco Road, Yauco, Guayanilla, Tallaboa, Coamo Springs, Humacao, Mameyes, El Yunque, Aguas Buenas, Caguas, Río Piedras, Bayamón, Toa Alta, Algarrobo, Arecibo-Utuado Road, and Quebradillas.

Porto Rican specimens now in my collection:

No. 125, male, Yauco-Lares Road, Oct. 6, 1926.

No. 397, female, San Sebastián, April 11, 1927.

111. VIREO LATIMERI Baird. Latimer's Vireo. Bien-te-veo.

Latimer's Vireo is a common bird, but of somewhat local oceurrence in Porto Rico. It is most abundant in the dry brushy country of the south coastal region, but it is almost equally common on the brush-covered hills of the north side of the island. It is also found to some extent in the coffee woods at the western end of the island. Its song has been very aptly described by Miss Nina G. Spaulding as 
che-wichy-blur. In Spanish it is rendered as Bien-te-veo. The song has some variations.

I have observed Latimer's Vireos in the coffee woods at Añasco, Mayagüez, Las Marías, Consomo, Maricao and Montoso Mountain; on the south coast at El Faro de Cabo Rojo, Cartagena Lagoon, Parguera, Anegado Lagoon, Guánica Lagoon, Ensenada, Yauco, Guayanilla, Tallaboa and Coamo Springs; and on the north side of the island at Vega Alta, Algarrobo, Arecibo-Utuado Road, Quebradillas and San Sebastián.

Two stomachs contained 72.5 per cent animal matter and 17.5 per cent vegetable matter. The latter consisted of seeds and drupes, the former of insects and their eggs. A walking stick (30 per cent), weevils (14 per cent), an Elaterid beetle (1.5 per cent), and nine moth eggs (10 per cent) were found.

Porto Rican specimens now in my collection:

No. 139, female, Anegado Lagoon, March 29, 1924.

No. 254, male, Ensenada, Nov. 20, 1926.

No. 255, male, Ensenada, Nov. 20, 1926.

\section{TIREO OLIVACEUS OLIVACEUS (Linné). Jamaican Vireo. Julián Chiví.}

The Jamaican Vireo is a common summer resident in Porto Rico, usually arriving in February (sometimes late in January) and leaving in September. From the time of its arrival until August its characteristic song of John-to-whit is heard on every side. For the last few weeks of its stay with us the song is seldom heard. The species is found wherever there are trees.

Spring-arrival dates are February 12, 1922, February 14, 1924, January 27, 1927, February 18, 1928, February 18, 1929 and February 15, 1930, all at Mayagüez.

Late fall dates are September 8, 1924, September 10, 1927 and September 11, 1929, all at Mayagüez. I was attracted to the bird seen September 11, 1929 by hearing it sing its regular song, but much more softly and more slowly than during the breeding season. The bird was observed closely as it fed among the blossoms of a tree.

A stomach from Maricao contained 6 per cent of vegetable matter (four small seeds), and 94 per cent of animal matter (a Coreid bug, eight Lepidopterous larvae, two Lepidopterous pupae, and two fleabeetles, Cryptocephalus krugi).

Localities at which I have observed Jamaican Vireos are: Aguada, Moca, San Sebastián, Aguada, Rincón, Añasco, Mayagüez, Consomo, 
Maricao, Las Marías, Hormigueros, Cabo Rojo, San Germán, Monte Grande, Sabana Grande, Faro de Cabo Rojo, Cartagena Lagoon, Parguera, Guayanilla, Jayuya, Orocovis, Ponce, Pastillo, Juana Díaz, Coamo Springs, Mameyes, El Yunque, Toa Alta, Vega Alta, Algarrobo, Manatí and Quebradillas.

Porto Rican specimens now in my collection:

No. 366, male, El Yunque (1,700 feet), Feb. 22, 1927.

No. 616, male, Mayagüez, April 20, 1928.

No. 726, female, Maricao, March 16, 1929.

\section{COEREBA PORTORICENSIS PORTORICENSIS (Bryant). Porto Rican Honey Creeper. Reinita.}

The Honey Creeper is the most abundant and generally distributed bird in Porto Rico. It is common everywhere and in every type of country from the highest mountain forests to the mangrove swamps of the coasts. It is less common than elsewhere in the brushy semiarid regions of the south coast.

Honey Creeper nests are familiar sights at all times of the year. Many dummy nests are built, and often torn down again as soon as finished to reuse the material in other nests, while others are used as sleeping quarters. The number of dummy nests found is greater than that of the nests used for breeding. Usually the nests are placed in trees at heights of from six to thirty-five feet from the ground. Ordinarily the nests are made of grasses and other plant fibers. Sometimes near where wild cotton is grown considerable quantities of the cotton is incorporated in the nests, and I have seen some nests which were made almost entirely of it.

Two extra low nests that I have found at Mayagüez were, one five feet in a coffee bush on February 13, 1928 containing five eggs, and another five feet in a spiny tree on May 2, 1928 containing three well fledged young which flew from the nest on my approach. It was only with difficulty that I captured one of them. A nest found at Boquerón on December 16, 1928 was placed even lower down, three and a half feet from the ground in a Lantana bush. It contained three newly hatched young.

The contents of three stomachs were examined. One contained a small weevil, another a beetle and a fly, and the third a small Lepidopterous larva and a beetle.

Honey Creepers are found at every locality on the island. I find them definitely recorded in my notes from the following: Point Borinquen, Aguadilla, San Sebastián, Aguada, Rincón, Añasco, Maya- 
güez, Consomo, Las Marías, Maricao, Montoso Mountain, Hormigueros, Joyuda, Cabo Rojo, Puerto Real, Boquerón, Faro de Cabo Rojo (not common), San Germán, Monte Grande, Cartagena Lagoon (not ccmmon), Parguera, Lajas, Anegado Lagoon, Guánica Lagoon, Ensenada, Yauco, Guayanilla, Peñuelas, Tallaboa, Ponce, Adjuntas, Jayuya, Orocovis, Juana Díaz, Villalba, Coamo, Coamo Springs, Salinas, Guayama, Aibonito, Cayey, Caguas, Cidra, Aguas Buenas, Maunabo, Yabucoa, Humacao, Naguabo, Fajardo, Luquillo, Mameyes, El Yunque (common to the summit), Río Grande, Carolina, Trujillo Alto, Río Piedras, Martín Peña, Santurce, San Juan, Palo Seco, Bayamón, Vega Alta, Vega Baja, Algarrobo, Laguna Tortuguera, Manatí, Ciales, Naranjito, Corozal, Arecibo, Utuado, Camuy, Quebradillas and Isabela.

Porto Rican specimens now in my collection:

No. 142, male, Mayagüiez, Dec. 21, 1923.

No. 143, female, Boquerón, Sept. 22, 1926.

No. 230, male, Mayagüez, Nov. 1, 1926.

No. 256, male, summit of Montoso Mountain, Nov. 24, 1926.

No. 611, male, imm. Mayagüez, April 15, 1928.

No. 612, male, imm. Mayagüez, April 15, 1928.

114. MNIOTILTA VARIA (Linné). Black and White Warbler. Reinita.

The Black and White Warbler is a fairly common and regular winter visitant, found mostly in wooded regions, but occasionally in brushy areas and mangrove swamps. It quite often sings soon after its arrival in the fall, and on one occasion (April 6, 1929 at Quebradillas) I observed one singing in the spring.

I once observed one of these warblers experiencing great difficulty in swallowing a lizard as long as itself. Two stomachs contained nothing but animal matter. Lepidopterous larvae formed 74 per cent, Fulgoridae 5 per cent, fleabeetles 6 per cent, a katydid nymph 5 per cent, a spider 3.5 per cent, and miscellaneous insects 6.5 per cent.

Early fall dates are October 12, 1924 (Mayagüez); October 6, 1926 (Monte Grande), October 29, 1927 (Nayagüez), and October 12, 1928 (Consomo).

Late spring dates are April 29, 1922 (Mayagüez); April 21, 1924 (Mayagüez) ; April 30, 1927 (Algarrobo) ; April 15, 1928 (Mayagüez); April 6, 1929 (Quebradillas), and April 24, 1930 (Algạrrobo; Nina G. Spaulding). 
Localities at which I have observed the species are: Añaseo, Mayagüez, Las Marías, Maricao, Consomo, Montoso Mountain, Monte Grande, Cartagena Lagoon, Yauco, Coamo Springs, Mameyes, El Yunque, Santurce, Algarrobo, and Quebradillas.

Porto Rican specimens now in my collection:

No. 148, male, Mameyes, Oct. 12, 1926.

No. 238, male, Mayagüez-Maricao Road, Nov. 8, 1926.

No. 656, female, Las Marías, Oct. 12, 1928.

\section{COMPSOTHLYPIS AMERICANA PUSILLA (Wilson). Northern} Parula Warbler. Reinita.

The Parula Warbler is the most abundant of the migrant warblers that winter in Porto Rico. It is found in brushy as well as wooded regions.

Three stomachs contained nothing but insects, largely beetles and their larvae, among which Cryptocephalus sp. could be recognized. Lepidopterous larvae (Geometrid and others) also formed 32.3 per cent of the stomach contents.

For several weeks before these warblers start for the North in the spring they are in full song. First song dates are March 22, 1924, March 15, 1927, March 28, 1928, and March 16, 1929. In 1930 one was heard to sing on February 23, but no others were heard until March 16, after which they were heard frequently. In the fall I have heard them sing upon only a few occasions in October (October 16 and 23, 1926). This and the Black and White Warbler are the only two species of migratory warblers that I have heard sing at all during their winter stay with us.

Early fall dates are: September 29, 1924 (Mayagüez); October 16, 1926 (Mayagüez); November 8, 1928 (Mayagüez), and November 11, 1929 (Añasco).

Late spring dates are: April 15, 1922 (Mayagüez); May 2, 1924 (Cartagena Lagoon) ; April 25, 1927 (Consomo); May 3, 1928 (Mayagüez); April 29, 1929 (San Germán), and April 24, 1930 (Algarrobo, Nina G. Spaulding).

Localities at which I have observed Parula Warblers are: Aguada, San Sebastián, Añasco, Mayagüez, Consomo, Las Marías, Maricao, Montoso Mountain, Hormigueros, San Germán, Puerto Real, Boquerón, Cartagena Lagoon, Parguera, Anegado Lagoon, Ensenada, Yauco, Peñuelas, Ponce, Coamo Springs, Algarrobo, and Quebradillas. 
Porto Rican specimens now in my collection:

No. 241, Mayagüez, Nov. 10, 1926.

No. 666, male, Montoso Mt., Nov. 17, 1928.

No. 670, female, San Sebastián, Nov. 24, 1928.

No. 718, male, Coamo Springs, Feb. 10, 1929.

116. DENDROICA TIGRINA (Gmelin). Cape May Warbler. Reinita.

The Cape May Warbler is a very rare winter visitant in Porto. Rico. At Mayagüez I saw one on February 19, 1922, one on March 17, 1922, and an adult male on March 16, 1929. On Montoso Mountain on November 24, 1926 I shot two, but was unable to recovereither. At Cartagena Lagoon I observed one on November 30, 1923. Miss Nina G. Spaulding reports seeing one at Santurce on February 19, 1930.

117. DENDROICA PETECHIA CRUCIANA Sundevall. Porto Rican Golden Warbler. Canario. Canario de Manglares.

The Golden Warbler is a common resident in Porto Rico. It is. most abundant in the mangrove swamps. It is common at Cartagena Lagoon. In some places it is found in dry brushy regions, and in: a few places in the coastal plain, as at Boquerón and Lajas, it is. even found in the shade trees in the towns.

Stomachs contained nothing but insects.

I have observed Golden Warblers at Aguada, Añasco, Mayagüez: (Caño Corazón, mouth of the Guanajibo River, and Correccional' Point), Hormigueros, Joyuda, Puerto Real, Cabo Rojo, Boquerón,. Faro de Cabo Rojo, Cartagena Lagoon, Lajas, Parguera, Cayo Enrique, Guánica Lagoon, Anegado Lagoon, Guayanilla, Tallaboa, Pastillo, Santa Isabel, Coamo Springs, Patillas, Fajardo, Río Blanco, San Juan, Laguna Tortuguera, Camuy, and Quebradillas.

Porto Rican specimens now in my collection:

No. 154, male, Cartagena Lagoon, March 17, 1924.

No. 233, male, Puerto Real, Nov. 3, 1926.

No. 609, male, Boquerón, April 16, 1928.

No. 633, male, Boquerón, Sept. 3, 1928.

No. 739, male, Cartagena Lagoon, March 9, 1929.

118. DENDROICA MAGNOLIA (Wilson). Magnolia Warbler. Reinita.

I have seen none since those recorded in my "Birds of the Cartagena Lagoon". 
119. DENDROICA CAERULESCENS CAERULESCENS (Gmelin). Blackthroated Blue Warbler: Reinita.

The Black-throated Blue Warbler is a common winter visitant in the wooded hills of Porto Rico, but it is rare near the coast. I have collected specimens at Añasco and on Montoso Mountain. A stomach contained nothing but insects, among which a fleabeetle (Cryptocephalus sp) was recognized.

Early fall dates are October 23, 1926 (Mayagüez-Maricao Road), and October 12, 1928 (Consomo). My latest spring date is April 15, 1922 (Maricao).

Localities at which I have observed the species are: Aguada, Añasco, Mayagüez, Consomo, Maricao, Montoso Mountain, Monte Grande, Aibonito and EI Yunque.

Porto Rican specimen now in my collection: No. 668, male, Montoso Mt., Nov. 17, 1928.

120. DENDROICA CORONATA (Linné). Myrtle Warbler. Reinita.

The Myrtle Warbler is a rather irregularly and locally common winter visitant in Porto Rico. It occurs most commonly in rather dry brushy regions. It does not arrive until well along in the winter, and is the first of the North American migrants to leave in the spring. It is more abundant during the latter part of its stay.

The food in two stomachs consisted entirely of animal matter, of which spiders formed 7.5 per cent, moths 10 per cent, weevils 7.5 per cent, and Lepidopterous larvae 5 per cent. A little sand, forming 4 per cent of the total contents, was also found.

Early arrival dates are December 14, 1923 (Cartagena Lagoon); November 20, 1926 (hills south of Anegado Lagoon); December 10, 1927 (Cartagena Lagoon), and December 16, 1928 (Cartagena Lagoon).

Late spring dates are: April 8, 1922 (Cartagena Lagoon); April 1, 1924 (Cartagena Lagoon); March 28, 1927 (Cartagena Lagoon); April 7, 1928 (Cartagena Lagoon), and March 24, 1929 (Coamo Springs).

Localities at which I have observed this warbler are: Mayagüez (rare); Boquerón, Faro de Cabo Rojo, Cartagena Lagoon (irregularly common), Anegado Lagoon, Coamo Springs, and Algarrobo.

Porto Rican specimens now in my collection: No. 252, male, imm., hills south of Anegado Lagoon, Nov. 20, 1926. No. 375, female, Cartagena Lagoon, March 7, 1927. 
121. DENDROICA DOMINICA DOMINICA (Linné). Yellow-throated Warbler. Reinita.

The Yellow-throated Warbler is a rare winter visitant to Porto Rico. At Mayagüez I have recorded single birds on five occasions (November 11, 1921; December 31, 1921; December 19, 1923; December 27, 1923, and January 23, 1924). On December 18, 1926 I collected a male in a cocoanut grove at Boquerón. Its stomach contained insects, mainly Coleoptera, but also including one Lepidopterous larva.

Porto Rican specimen now in my collection: No. 275, male, Boquerón, Dec. 18, 1926.

\section{DENDROICA ADELAIDAE Baird. Adelaide's Warbler. Reinita.}

Adelaide's Warbler is a common but locally distributed bird in Porto Rico. It is preeminently a bird of dry brushy regions, and of the tangled brushy vegetation found on limestone hills. It is very active, and feeds where the vegetation is dense; for that reason it is rather hard to observe, even where its persistent song is heard on every side. The song is a loud trill.

A stomach from near Mayagüez was filled with insects and their eggs. An aphid, beetles (including a small Coccinellid), Diptera, and two kinds of insect eggs were noted.

Localities at which I have observed Adelaide's Warblers are: Point Borinquen, Aguadilla, Aguada, Mayagüez (Correecional Point), Puerto Real, Monte Grande, Boquerón, Faro de Cabo Rojo, Cartagena Lagoon, Parguera, Anegado Lagoon, Guánica Lagoon, Ensenada, Yauco, Guayanilla, Tallaboa, Coamo Springs, Mameyes, Vega Alta. Algarrobo and Quebradillas.

Porto Rican specimens now in my collection:

No. 150, male, Cartagena Lagoon, Sept. 23, 1924.

No. 151, female, Guánica Lagoon, Oct. 3, 1924.

No. 242, Imm., Mayagüez (Correccional Point), Nov. 10, 1926.

No. 734, male, Cartagena Lagoon, Feb. 14, 1929.

123. DENDROICA STRIATA (J. R. Forster). Blackpoll Warbler. Reinita.

On only one occasion have I observed the Blackpoll Warbler in Porto Rico. That was on October 13, 1928, when the trees and shrubs south of Cartagena Lagoon fairly swarmed with them. I counted up to 150 of them, and am sure there were many more. Two were collected. Their stomachs contained comminuted insects, 
largely small Homoptera. A small Lepidopterous larva and a few Coleopterous fragments were also recognized.

Porto Rican specimens now in my collection:

No. 657, female, Cartagena Lagoon, Oct. 13, 1928.

No. 658, male, Cartagena Lagoon, Oct. 13, 1928.

124. DENDROICA DISCOLOR (Vieillot). Prairie Warbler. Reinita.

The Prairie Warbler is a winter visitant in Porto Rico. Most years it is quite common, but some years it is very rare. In the winter of 1928-29 it was extremely scarce. While here it frequents for the most part brushy regions, and is particularly common in the bushes growing back of beaches. On a number of occasions I have observed it in coffee woods.

Two stomachs were filled with insects, almost exclusively Coleoptera. Small fleabeetles and small Elateridae figured largely.

Early fall dates are September 20, 1924 (Cartagena Lagoon); October 2, 1926 (Guánica Lagoon), and October 29, 1927 (Mayagüez).

Late spring dates are April 22, 1922, April 4, 1924, April 23, 1927, and April 7, 1928 at Cartagena Lagoon, and April 3, 1930 at Mayagüez.

Localities at which I have observed Prairie Warblers are: Aguada, Mayagüez, Puerto Real, Boquerón, Faro de Cabo Rojo, Cartagena Lagoon, Lajas, Anegado Lagoon, Guánica Lagoon, Ensenada, Coamo Springs, Mameyes, Algarrobo, and along the Arecibo-Utuado Road.

Porto Rican specimens now in my collection:

No. 360, female, Boquerón, Feb. 14, 1927.

No. 661, male, Puerto Real, Nov. 6, 1928.

125. DENDROICA PALMARUM PALMARUM (Gmelin). Palm

Warbler. Reinita.

The Palm Warbler is a rare winter visitant to Porto Rico. On three occasions (December 18, 1926, February 14, 1927 and December 16, 1928) I have observed single individuals at the same spot back of the beach at Boquerón.

Porto Rican specimen now in my collection:

No. 708, female, Boquerón, Dec. 16, 1928.

126. SEIURUS NOVEBORACENSIS NOVEBORACENSIS (Gmelin).)

Water-thrush. Pizpita. Pizpita de manglares.

The Water-thrush is an abundant winter visitant in Porto Rico. It is found most abundantly in the mangroves, but is common at 
fresh water lagoons and along streams. Next to the Parula Warbler I believe this to be the most abundant wintering warbler in Porto Rico. Stomachs contained comminuted insects, largely Coleoptera.

Early fall dates are: September 3, 1924 (Cartagena Lagoon); September 22, 1926 (Boquerón); September 16, 1927 (Mayagüez); September 21, 1928 (Mayagüez); September 29, 1929 (Coamo Springs).

Late spring dates are: April 22, 1922 (Cartagena Lagoon); April 30, 1924 (Cartagena Lagoon) ; April 23, 1927 (Cartagena Lagoon); April 30, 1928 (Joyuda); April 18, 1929 (Boquerón), and April 17, 1930 (Aguada).

Localities at which I have observed Water-thrushes are: Aguada, Añasco, Mayagüez, Las Marías, Consomo, Maricao, Hormigueros, San Germán, Joyuda, Puerto Real, Boquerón, Faro de Cabo Rojo, Cartagena Lagoon, Anegado Lagoon, Guánica Lagoon, Peñuelas, LaresYauco Road, Ponce, Santa Isabel, Coamo Springs, Fajardo, Mameyes, Cidra, and Quebradillas.

Porto Rican specimens now in my collection:

No. 161, male, Cartagena Lagoon, April 8, 1924.

No. 163, male, San Germán, Oct. 9, 1926.

No. 232, female, Puerto Real, Nov. 3, 1926.

No. 603, male, Consomo, April 6, 1928.

No. 604, male, Consomo, April 6, 1928.

127. SEIURUS NOVEBORACENSIS NOTABILIS Ridgway. Grinnell's Water-thrush. Pizpita. Pizpita de Manglares.

This is probably a rare winter visitant in Porto Rico. The only positive record I have is a male which I shot at Mayagüez on November 29, 1926. Its stomach was empty.

Porto Rican specimen now in my collection:

No. 261, male, Mayagüez, Nov. 29, 1926.

128. SEIURUS MOTACILLA (Vieillot). Louisiana Water-thrush. Pizpita.

The Louisiana Water-thrush is a fairly common winter visitant in Porto Rico. It frequents mostly swiftly running streams in the interior hills, but is found to some extent along streams in the coastal plain, at fresh water lagoons, and even in the mangrove swamps. Two stomachs contained nothing but comminuted insects, among which a small Carabid beetle and a small wingless cockroach were recognized. 
Early fall dates are: September 6, 1924 (Mayagüez); October 29, 1927 (Mayagüez), and October 12, 1928 (Consomo).

Late spring dates are: April 10, 1924 (Mayagüez); April 21, 1927 (Mayagüez), and April 14, 1928 (Mayagüez).

Localities at which I have observed this species are: Añasco, Mayagüez, Consomo, Las Marías, Maricao, Cartagena Lagoon, and Coamo. Springs.

Porto Rican specimen now in my collection: No. 270, male, Las Marías, Dec. 4, 1926.

129. SEIURUS AUROCAPILLUS $\triangle U R O C A P I L L U S$ (Linné). Ovenbird. Pizpita. Pizpita Dorada.

The Ovenbird is a common winter visitant in Porto Rico. It is: found most frequently in the coffee woods, but it is not unusual to find it in brushy regions. It never sings while with us, but its vigorous scold note can often be heard protesting against some passing. mongoose or other would-be enemy.

Two stomachs contained 89 per cent vegetable matter and 11 per cent animal matter. The latter consisted of beetles and a smooth white caterpillar. The vegetable matter was formed of seeds and small fruits. Considerable sand was also found in one of the stomachs.

Early fall dates are: September 24, 1924 (Mayagüez); September 18, 1927 (Mayagüez); and October 12, 1928 (Mayagüez-Maricao. Road).

Late spring dates are: April 20, 1922, April 10, 1924, April 22, 1928, and April 25, 1929 at Mayagüez, and April 16, 1930 at Consomo.

Localities at which I have observed Ovenbirds are: Añasco, Mayagüez, Maricao, Consomo, Las Marías, Puerto Real, Monte Grande, Cartagena Lagoon, Yauco, and Coamo Springs.

Porto Rican specimens now in my collection: No. 165, male, Mayagüez-Maricao Road, Oct. 23, 1926. No. 247, female, Añasco, Nov. 17, 1926.

\section{GEOTHLYPIS TRICHAS BRACHIDACTYLA (Swainson). Northern} Yellowthroat. Reinita.

The Yellowthroat is a very rare winter visitant in Porto Rico. On April 18, 1924 I observed a male at Cartagena Lagoon, and on December 10, 1927 a pair in a flooded weed-grown canefield at the. 
edge of Cartagena Lagoon. On January 5, 1930 I heard the characteristic scold notes of this species in thick undergrowth near a stream at Hormigueros.

131. SETOPHAGA RUTICILLA. (Linné). Redstart. Reinita. Candelita.

The Redstart is a common winter visitant in Porto Rico. It is most abundant in wooded regions, but is also found not uncommonly in shade trees, mangrove swamps, and brushy regions. Birds in the female and immature male plumages are more frequently seen than brilliantly plumaged males.

Early fall dates are: October 7, 1924 (Cartagena Lagoon); September 22, 1926 (Boquerón), and October 6, 1928 (Guayama).

Late spring dates are: April 26, 1924 (Faro de Cabo Rojo); May 3, 1928 (Mayagüez) ; April 27, 1929 (Hormigueros), and April 27, 1930 (Mayagüez). On May 3, 1928 five in female plumage were noted in a single tree at Mayagüez.

Localities at which I have observed Redstarts are: San Sebastián, Añasco, Mayagüez, Maricao, Las Marías, Consomo, Montoso Mountain, Hormigueros, San Germán, Monte Grande, Joyuda, Puerto Real, Boquerón, Cartagena Lagoon, Ensenada, Coamo Springs, Guayama, Río Piedras and Algarrobo.

Porto Rican specimen now in my collection:

No. 237, male, Mayagüez-Maricao Road, Nov. 8, 1926.

132. SPERMESTES CUCULLATUS CUCULLATUS Swainson. Hooded Weaver Finch. Diablito. Gorrión.

The Hooded Weaver Finch is a species introduced from West Africa. It is a locally common species on the coastal plain of Porto Rico. It is rare in the hills, and is less common on the dry south coast than in other parts of the coastal plain. Occasionally this species is found in mixed flocks with the Scarlet-cheeked species. Its principal food is the seeds of the guinea grass.

Localities at which I have observed the species are: San Sehastián, Añasco, Mayagüez, San Germán, Monte Grande, Cabo Rojo, Boquerón, Cartagena Lagoon, Lajas, Yauco-Lares Road, Ciales, Tillalba-Ciales Road, Mameyes and Río Piedras.

Porto Rican specimens now in my collection:

No. 262, male, Mayagüez, Nov. 29, 1926.

No. 545, male, Boquerón, Sept. 10, 1927. 
133. ESTRILDA MELPODA MELPODA (Vieillot). Scarlet-cheeked Weaver Finch. Chamorro. Gorrión.

The Scarlet-cheeked Weaver Finch is another species introduced from West Africa, but in Porto Rico it is confined to the southwest corner of the island. It has been recorded from Añasco to Santa Isabel, but is common only from Mayagüez to Anegado Lagoon. Its center of abundance is in the region from Boquerón to Cartagena Lagoon. I have personally encountered the species only at the following localities: Añasco, Mayagüez, Monte Grande, Boquerón, Cartagena Lagoon, Anegado Lagoon, Guánica Lagoon, and Peñuelas.

Porto Rican specimens now in my collection:

No. 181, male, Cartagena Lagoon, March 21, 1926.

No. 239, male, Mayagüez, Nov. 10, 1926.

No. 659, female, Boquerón, Oct. 27, 1928.

\section{AGELAIUS XANTHOMUS (Sclater). Yellow-shouldered Blackbird. Mariquita.}

The Yellow-shouldered Blackbird is a common resident in Porto Rico. It is essentially a bird of the lowlands, but is by no means confined to the swamps. It usually nests in small colonies in palms or other tall trees. The birds are gregarious, and occur in small flocks at all times. When it is not the breeding season as many as fifty birds may occur in a flock. At that time mixed flocks of this species and Holoquiscalus are also frequently encountered. During the winter a large flock of Yellow-shouldered Blackbirds congregates near the poultry yards of the College of Agriculture at Mayagüez to pick up what grain they can steal. But on the whole the species is beneficial and it subsists largely on insects. I found Lepidopterous larvae and pupae forming nearly three-quarters of the food in the stomachs that I examined.

Localities at which I have observed the species are: Aguada, Rincón, Añasco, Mayagüez, Joyuda, Hormigueros, Filial Amor, Cabo Rojo, San Germán, Sabana Grande, Boquerón, Faro de Cabo Rojo, Cartagena Lagoon, Lajas, Anegado Lagoon, Ensenada, Tallaboa, Peñuelas, Juana Díaz, Coamo Springs, Central Aguirre, Río Piedras, Toa Baja, Comerío, hills above Ciales, Manatí, Arecibo, and Isabela.

Porto Rican specimens now in my collection:

No. 167, male, Cartagena Lagoon, April 1, 1924.

No. 228, female, Cartagena Lagoon, Oct. 30, 1926.

No. 229, female, Cartagena Lagoon, Oct. 30, 1926.

No. 547, female, Cartagena Lagoon, Sept. 17, 1927. 
No. 596, male, Mayagüez, March 14, 1928.

No. 598, male, Mayagüez, March 14, 1928.

No. 599, male, Mayagüez; March 14, 1928.

No. 600, male, Mayagüez, March 14, 1928.

No. 601, female, Mayagüez, March 14, 1928.

No. 602, female, Mayagüez, March 14, 1928.

135. ICTERUS PORTORICENSIS Bryant. Porto Rican Oriole. Calandria.

The Oriole is a common resident, universally distributed wherever there are trees. However, I did not find it above an altitude of 1,700 feet on El Yunque. Usually this species occurs singly, or in pairs or small family groups. On one occasion (February 26, 1929 at Mayagüez) I observed the very unusual sight of a flock of thirteen adults and one bird in immature plumage. They flew overhead making a noisy chorus of call notes.

Four stomachs contained 60.5 per cent of animal matter and 29.5 per cent of vegetable material. The latter consisted of small greenish seeds and red-seeded berries. Coleoptera formed 26 per cent of the contents, a centipede 21.2 per cent, and Lepidopterous larvae 10.5 per cent.

The Oriole is perhaps the finest songster in Porto Rico, but it does not sing very freely, although the song is heard occasionally at all times of the year.

I have observed Orioles at: San Sebastián, Aguada, Rincón, Añasco, Mayagüez, Maricao, Consomo, Las Marías, Montoso Mountain, Hormigueros, Cabo Rojo, Monte Grande, Sabana Grande, Joyuda, Puerto Real, Boquerón, Faro de Cabo Rojo, Cartagena, Lagoon, Parguera, Anegado Lagoon, Guánica Lagoon, Ensenada, Yauco, Tallaboa, Peñuelas, Jayuya, Villalba, Coamo Springs, Maunabo, Yabucoa, Mameyes, El Yunque, Aguas Buenas, Juncos, Santurce, Vega Alta, Algarrobo, Arecibo-Utuado Road, Morovis, and Quebradillas.

Porto Rican specimens now in my collection:

No. 170, male, imm., Mayagüez, Dec. 25, 1923.

No. 171, male, ad., Guánica Lagoon, Oct. 3, 1924.

No. 172, male, ad., Boquerón, Sept. 22, 1926.

No. 173, male, imm., Mameyes, Oct. 12, 1926.

No. 717, female, imm., Monte Grande, Feb. 7, 1929.

No. 740, male, ad., Maricao, March 16, 1929. 
136. HOLOQUISCALUS NIGER BRACHYPTERUS (Cassin). Porto Rican Grackle. Mozambique. Chango. Pichón Prieto.

The Grackle is the most abundant bird in the coastal plain of Porto Rico, though it is somewhat rare in the dry sagebrush regions. It is also found in the foothills, but not in the high mountains.

The Grackle nests from March to August, usually in palm trees, but often in other trees, or even in the cattails. On August 13, 1927 near Cartagena Lagoon I found a colony of nests in a Guazama tree containing new hatched young. On March 19, 1927, near Mr. Burlingame's house at Algarrobo I observed a colony of ten nests in a Ceiba tree. Mr. Burlingame told me that they had been nesting for about two weeks. On April 27, 1928 I observed a pair nest building in a cocoanut palm at Hormigueros. On March 22, 1930 I made observation of a pair which had a nest of coarse grass built on the girders of a large iron bridge over a river near Toa Alta.

On one occasion I watched a Grackle clinging upside down on the udder of a cow, picking off something. The cow seemed to enjoy the process and stayed perfectly still.

I have observed Grackles at: Aguadilla, San Sebastián, Coloso, Aguada, Rincón, Mayagüez, Joyuda (rare), Puerto Real, Hormigueros, Cabo Rojo, Filial Amor, Monte Grande, San Germán, Sabana Grande, Guanaquilla, Boquerón, Faro de Cabo Rojo (rare), Cartagena Lagoon, Lajas, Parguera, Anegado Lagoon, Guánica Lagoon, Ensenada, Yauco, Guayanilla, Peñuelas, Jayuya, Orocovis, Ponce, Santa Isabel, Coamo Springs, Salinas, Central Aguirre, Guayama, Maunabo, Yabucoa, Humacao, Fajardo, Luquillo, Loíza, Mameyes, El Yunque (at low elevations), Río Grande, Trujillo Alto, Río Piedras, Martin Peña, San Juan, Caguas, San Lorenzo, Aguas Buenas, Juncos, Pueblo del Río, Bayamón, Vega Alta, Toa Baja, Toa Alta, San Vicente, Vega Baja, Algarrobo, Manatí, Ciales, Barceloneta, Bajadero, Florida, Cidra, Comerío, Naranjito, Arecibo, Hatillo, Camuy, Quebradillas and Isabela.

Porto Rican specimens now in my collection:

No. 178, female, Cartagena Lagoon, March 21, 1924.

No. 179. female, Cabo Rojo, Oct. 6, 1926.

No. 180, male, Cabo Rojo, Oct. 6, 1926.

No. 266, female, Aguada, Dec. 1, 1926.

No. 709, female, Cartagena Lagoon, Jan. 12, 1929.

No. 710, male, Cartagena Lagoon, Nov. 10, 1928. 


\section{NESOSPINGUS SPECULIFERUS (Lawrence). Porto Rican} Tanager. Llorón.

I have found Nesospingus only on the forested slopes of El Yunque above 1,700 feet elevation, and in the hills in the vicinity of Maricao. In both these regions is it a common bird. In the second growth woods in the National Forest near Maricao this is the commonest bird, even exceeding the Money Creeper in abundance. Birds collected in February were apparently nearly ready to breed.

The iris of these birds is brown, of about the same shade as the wing. The upper mandible is dusky brown, and the lower is horn color. The legs and feet are bluish gray. The soles are yellow, and the claws grayish brown.

Three stomachs contained 93.3 per cent of vegetable matter and 6.7 per cent of animal matter. The latter consisted of a large Lepidopterous larva in one stomach. The vegetable matter was formed of seeds and small fruits.

Porto Rican specimens now in my collection:

No. 362, male, El Yunque, Feb. 20, 1927.

No. 363, male, El Yunque, Feb. 20, 1927.

No. 364, female, El Yunque, Feb. 21, 1927.

No. 365, male, El Yunque, Feb. 22, 1927.

No. 593, female, East of Maricao, Feb. 4, 1928.

No. 712, female, Maricao, Jan. 26, 1929.

No. 736, male, Maricao, March 16, 1929.

138. SPINDALIS PORTORICENSIS (Bryant). Porto Rican Spindalis.

Reina Mora. Come Ñame.

The Spindalis is a very common bird in the wooded regions of Porto Rico, in the lowlands and hilly country alike. It is sometimes found even in the mangrove swamps. When food is abundant it is often found in loose flocks, sometimes containing as many as twenty individuals. The food, as determined by field observations and by the examination of stomach contents, consists entirely of fruits.

The song of the Spindalis is inconspicuous and easily overlooked unless one is familiar with it, but once learned it is a song that one will hear frequently in many regions. The notes have much the same quality as those of the Honey Creeper, but they are slightly higher pitched, and are repeated in regular cadence, often for a considerable length of time. It might be described as a rather fine, squeaky, unmusical, wiry tswee, tswee, tsweey, continued more or 
less indefinitely, with a certain amount of rhythm. This song is frequently heard throughout the year, except during a short period from the middle of November until nearly the middle of January, when it is seldom heard. The Spindalis also has a faint, lisping tsweep call note, and I have heard fighting males make some harsh scolding notes which might be rendered as krukky-krurr-r-r-r.

On March 22, 1927 at Algarrobo I found a nest placed five and a half feet above the ground in a "cocorón" tree. The nest was a shallow cup-shaped affair, made of coarse plant stems, and lined with finer ones. It contained three young with their eyes not yet open. The brooding bird, which was in typical female plumage, but with a large, orange spot on its breast, was not at all shy, and came to feed and brood the young while I. was watching from within a few feet. The young were deep reddish orange, sparsely covered with gray fuzzy down.

Localities at which I have observed the Spindalis are: San Sebastián (common); Añasco (common); Rincón (rare); Mayagüez (common); Las Marías (common); Consomo (common); Maricao (common); Montoso Mountain (common); Joyuda and Puerto Real (in mangrove swamps); Monte Grande (common); San Germán; Boquerón (rare in mangrove swamps); Cartagena Lagoon (rare); Yauco; Peñuelas; Coamo Springs (common); Guayama; Aguas Buenas; Cidra; El Yunque (common); Algarrobo (common).

Porto Rican specimens now in my collection:

No. 184, male, Mayagüez, Oct. 16, 1926.

No. 185, male, Mayagüez-Maricao Road, Oct. 23, 1926.

No. 234, male, Puerto Real, Nov. 3, 1926.

No. 250, female, Mayagüez, Nov. 17, 1926.

No. 263, male, Mayagüez,, Nov. 29, 1926.

No. 355, male, Añasco, Jan. 24, 1927.

No. 614, male, imm., Mayagüez, April 17, 1928.

No. 733, female, Mayagüez, March 14, 1929.

139. TANAGRA SCLATERI (Sundevall). Porto Rican Euphonia. Canario del País. Jilguero.

The Euphonia is a bird that is somewhat locally distributed in Porto Rico, being found principally in the hills, and where mistletoe is abundant, though I have observed the species practically at sea level near Mayagüez.

I have observed this species only at Añasco, Mayagüez, Montoso Mountain, Consomo, and on El Yunque (at 1,500 feet). 
Porto Rican specimens now in my collection:

No. 244, male, Añasco, Nov. 13, 1926.

No. 271, male, Consomo, Dec. 4, 1926.

No. 272, female, Consomo, Dec. 4, 1926.

No. 367, female, El Yunque (1,500 feet), Feb. 22, 1927.

140. MELOSPIZA LINCOLNII (Audubon). Lincoln's Sparrow.

On December 14, 1923 I saw one in a brush pile near La Plata, but as the record is so unusual, and the specimen was not collected, the species can be listed only hypothetically for Porto Rico.

\section{TIARIS BICOLOR OMISSA Jardine. Carib Grassquit. Gorrión.}

The Carib Grassquit is an abundant resident in Porto Rico. It far exceeds the Bryant's Grassquit in abundance except at the extreme east end of the island, and in a few other limited localities. It is primarily a bird of the open country at lower levels, but at times occurs well up into the mountains and even in the coffee woods; indeed I have even found their nests in the coffee woods. On one occasion (September 22, 1926) I found a nest with two eggs in a mangrove swamp at Boquerón. It was placed four and a half feet above the water in a small mangrove.

Several stomachs contained nothing but seeds and small berries; also a little sand for grinding the seeds.

Localities at which I have observed Carib Grassquits are: Point Borinquen, Aguadilla, San Sebastián, Aguada, Rincón, Añasco, Mayagüez, Maricao, Consomo, Las Marías, Montoso Mountain, Joyuda, Puerto Real, Hormigueros, Cabo Rojo, Monte Grande, San Germán, Sabana Grande, Guanaquilla, Boquerón, Faro de Cabo Rojo, Cartagena Lagoon, Lajas, Parguera, Anegado Lagoon, Guánica Lagoon, Ensenada, Yauco, Lares-Yauco Road, Guayanilla, Tallaboa, Ponce, Juana Díaz, Guayabal Reservoir, Villalba, Coamo Springs, Salinas, Guayama, Patịllas, Maunabo, Humacao, Naguabo, Mameyes, Río Piedras, Santurce, San Juan, San Lorenzo, Juncos, Pueblo del Río, Bayamón, Vega Alta, Laguna Tortuguera, Algarrobo, Manatí, Ciales, Utuado, Camuy and Quebradillas.

Porto Rican specimens now in my collection:

No. 217, male, Yauco-Lares Road, Oct. 9, 1926.

No. 246, female, Añasco, Nov. 7, 1926.

No. 274, female, Anegado Lagoon, Dec. 18, 1926. 
142. TIARIS OLIVACEA BRYANTI (Ridgway). Bryant's Grassquit. Gorrión.

Bryant's Grassquit is a common resident in Porto Reo, but it is less common than the preceding species except in a few localities, such as the semi-barren low-lying hills at the east end of the island, and certain unwooded hills in the interior of the island. It is preeminently a bird of open and grassy country, and frequents thickets much less freely than its relative.

I have recorded the species at San Sebastián, Aguada, Rincón, Añasco, Mayagüez, Mayagüez-Maricao Road, Las Marías, Consomo, Montoso Mountain, Filial Amor, San Germán, Puerto Real, Faro de Cabo Rojo, Cartagena Lagoon, Lajas, Anegado Lagoon, Guánica Lagoon, Ensenada, Guayanilla, Peñuelas, Tallaboa, Ponce, Pastillo, Santa Isabel, Villalba, Coamo Springs, Guayama, Yabucoa, Humacao, Ceiba, Fajardo, Mameyes, El Yunque (at lower elevations), Trujillo Alto, Río Piedras, Bayamón, Juncos, Pueblo del Río, San Lorenzo, Las Piedras, Caguas, Naranjito, Vega Alta, Algarrobo, Manatí, Arecibo, Arecibo-Utuado Road, Utuado, Adjuntas, Utuado-Ponce Road, and Quebradillas.

Porto Rican specimens now in my collection:

No. 259, male, Mayagüez, Nov. 25, 1926.

No. 606, female, San Sebastián, April 14, 1928.

No. 667, male, Montoso Mountain, Nov. 17, 1928.

143. LOXIGILLA PORTORICENSIS (Daudin). Porto Rican Grosbeak. Capitan. Come Gandul. Capacho.

The Grosbeak is a common resident in Porto Rico wherever there is sufficient cover. It is an inhabitant of well wooded regions and dense thickets. Occasionally it is found in some of the more dense growths of acacia scrub in the drier parts of the island. It is not unusual to find it in mangrove swamps. It is very rare in the eastern part of the island. With the exception of a few birds noted on El Yunque I have never observed the species east of Vega Alta and Coamo Springs.

I have observed two occupied nests of this species. On March 22, 1927 at Algarrobo I discovered a nest seven feet from the ground in a mameyuelo tree. The nest was rather bulky, like a basket tipped partly on its side so that it was partly covered above. It was loosely constructed of plant stems and skeletonized leaves. In fact it appeared so sloppy that I would easily have overlooked it believing it to 
be an abandoned nest if I had not seen the incubating bird fly away. The nest contained three eggs, which were very light bluish green, spotted everywhere with reddish brown, the spots coalescing to some extent at the larger end.

The second nest was found on April 29, 1929 in some coffee woods near Mayagüez. It was made of coarse grasses, stems of plants bearing small fruits, and a little vegetable wool on the outside. The material used for the inside construction was coarser than that used outside; nevertheless the outside presented a very rough appearance, with fine stems projecting in every direction. The nest formed a very deep cup. It contained three very slightly incubated eggs. They were of the same color as those found in the first nest. Unfortunately two of them were accidentally broken before they could be measured, but the third measured $18 \times 12.5$ millimeters.

The loud characteristic song of the Grosbeak is heard to some extent at all times of the year, but far more frequently from February to June.

Of three stomachs, one contained solaneceous berries, another other berries, and the third finely ground seeds. Sand in two stomachs formed 20 per cent of the total contents.

Localities at which I have observed Porto Rican Grosbeaks are: San Sebastián, Añasco, Mayagüez, Maricao, Consomo, Montoso Mountain, Las Marías, Joyuda (rare), Monte Grande, Boquerón, Faro de Cabo Rojo (a few in brushy beach vegetation), Mariquita Hill (near Cartagena Lagoon), Parguera, hills south of Anegado Lagoon, Ensenada, Yauco, Tallaboa (in the dry acacia scrub), Ponce, Coamo Springs (not common), El Yunque, Vega Alta (common), Ciales, Utuado, Utuado-Adjuntas Road, and Quebradillas.

Porto Rican specimens now in my collection:

No. 240, male, Mayagüez, Nov. 10, 1926.

No. 245, male, Añasco, Nov. 17, 1926.

No. 249, male, Añasco, Nov. 17, 1926.

No. 552, female, Mayagüez, Dec. 13, 1927.

144. AMMODRAMUS SAVANNARUM BORINQUENSIS Peters.

Porto Rican Grasshopper Sparrow. Gorrión.

The Grasshopper Sparrow is a resident of dry grassy fields where the vegetation is not too high. In habits it is similar to its North American relative. The only nest I have ever found has been previously recorded in my "Birds of the Cartagena Lagoon". 
The only localities at which I have observed the species are Cartagena Lagoon, Anegado Lagoon, Guánica Lagoon and Arecibo.

Porto Rican specimens now in my collection:

No. 198, male, Cartagena Lagoon, Oct. 3, 1924.

No. 199, male, Cartagena Lagoon, Sept. 25, 1926. 
PLATE I.

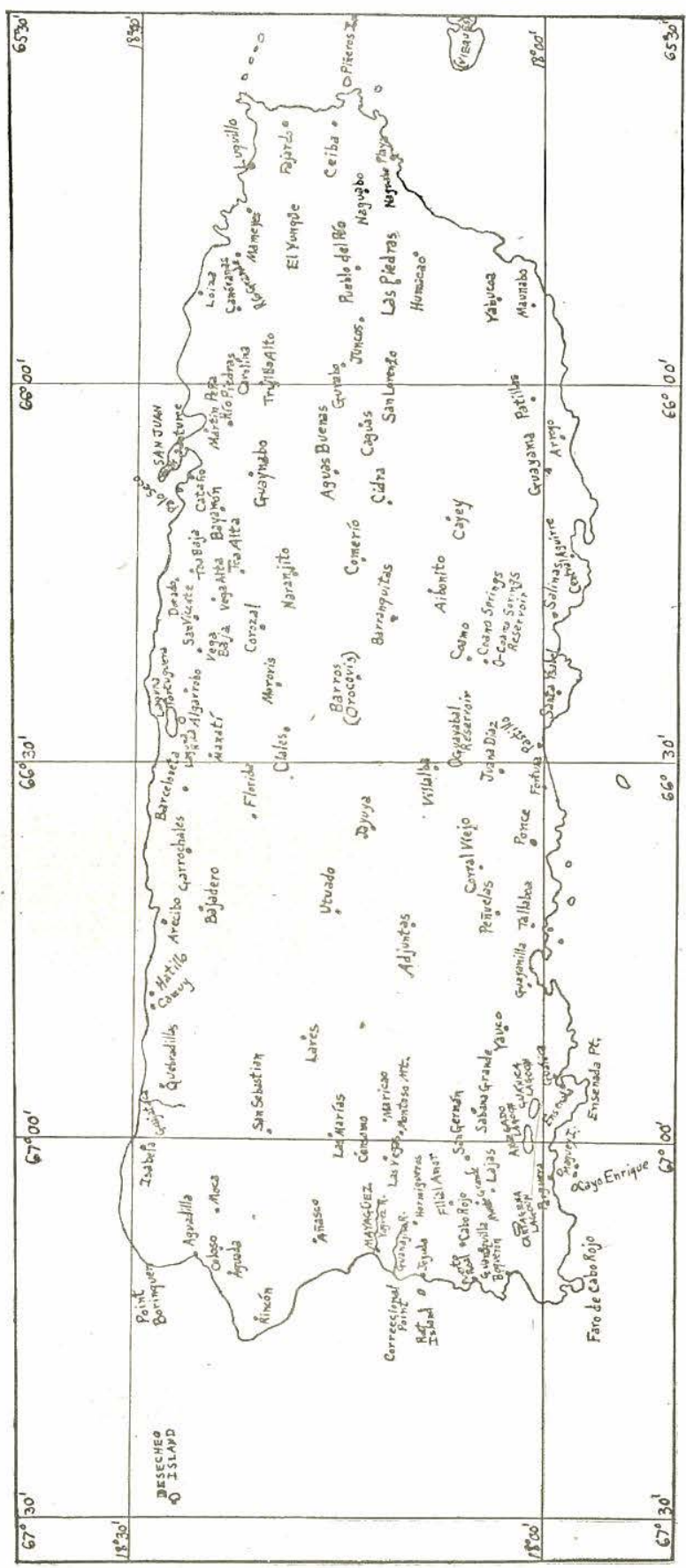




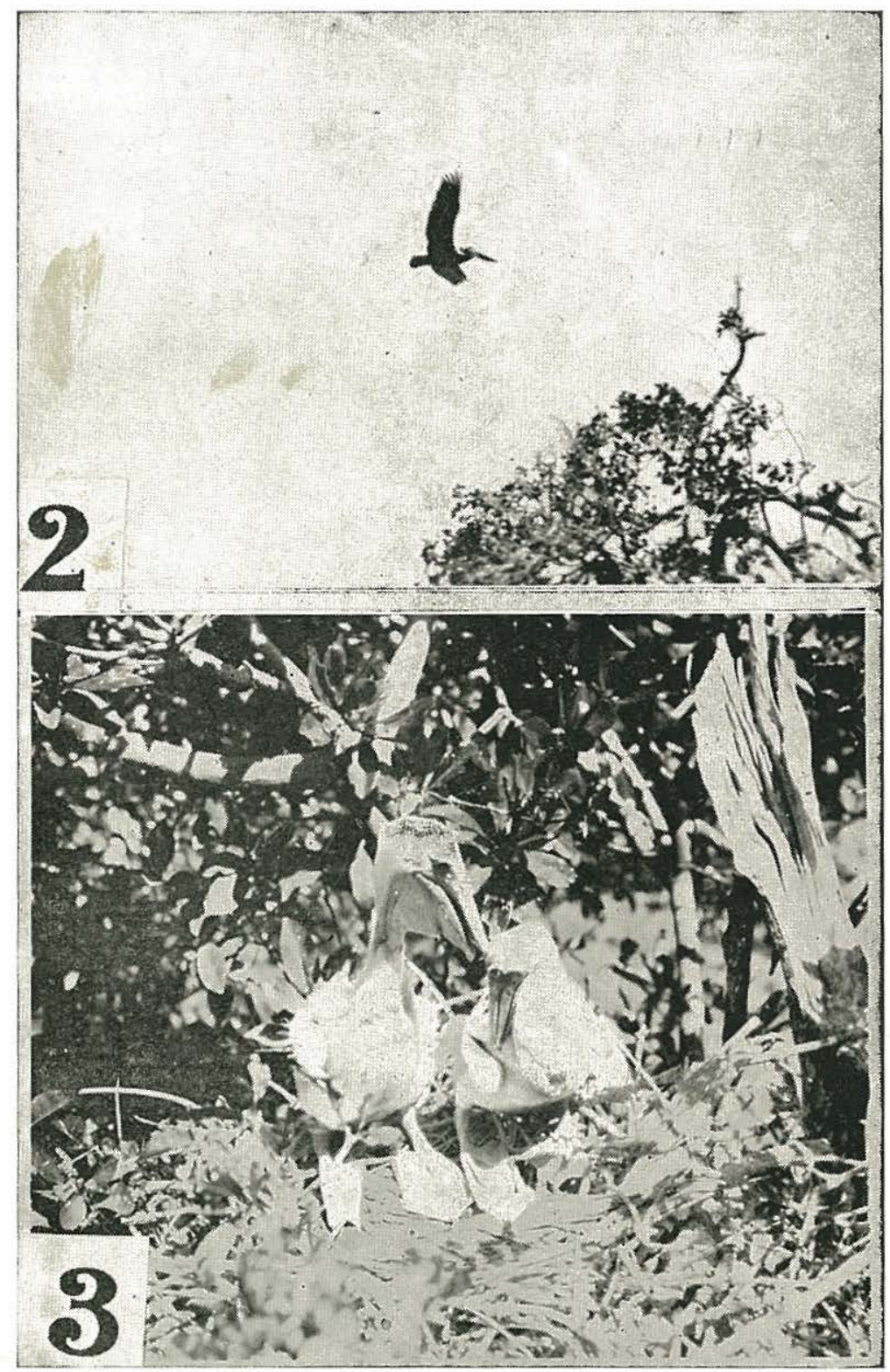




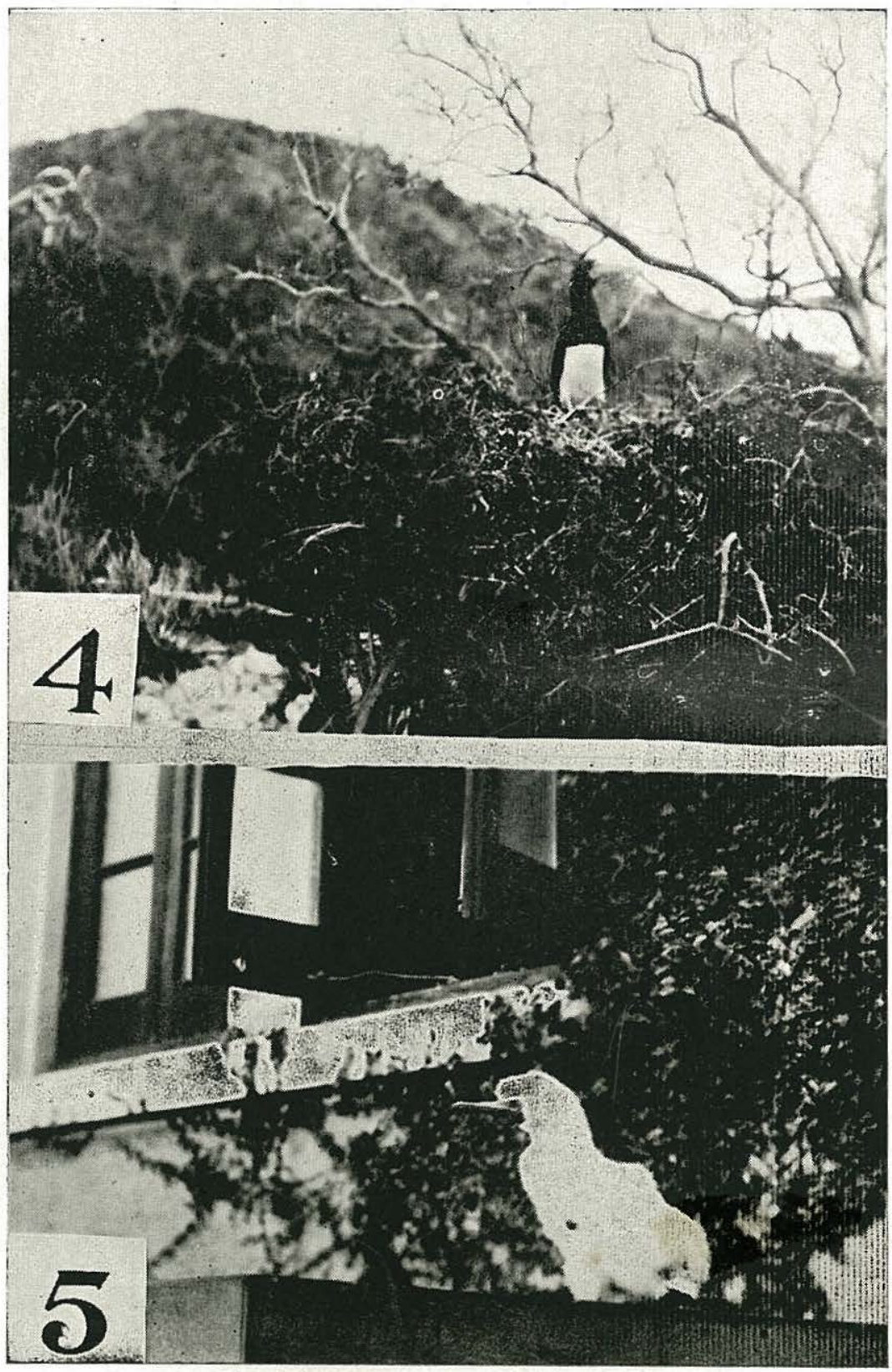


PLATE IV.

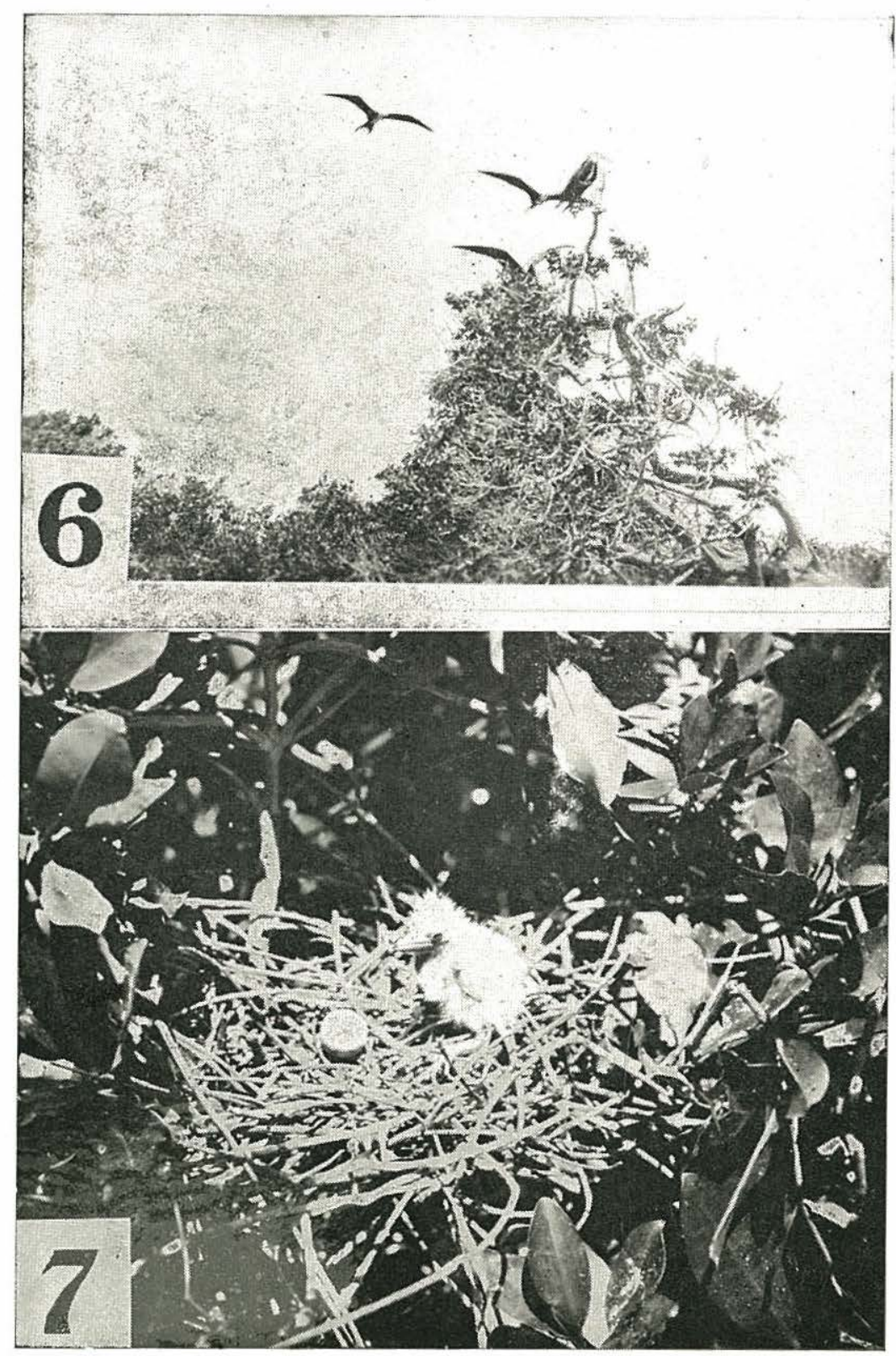




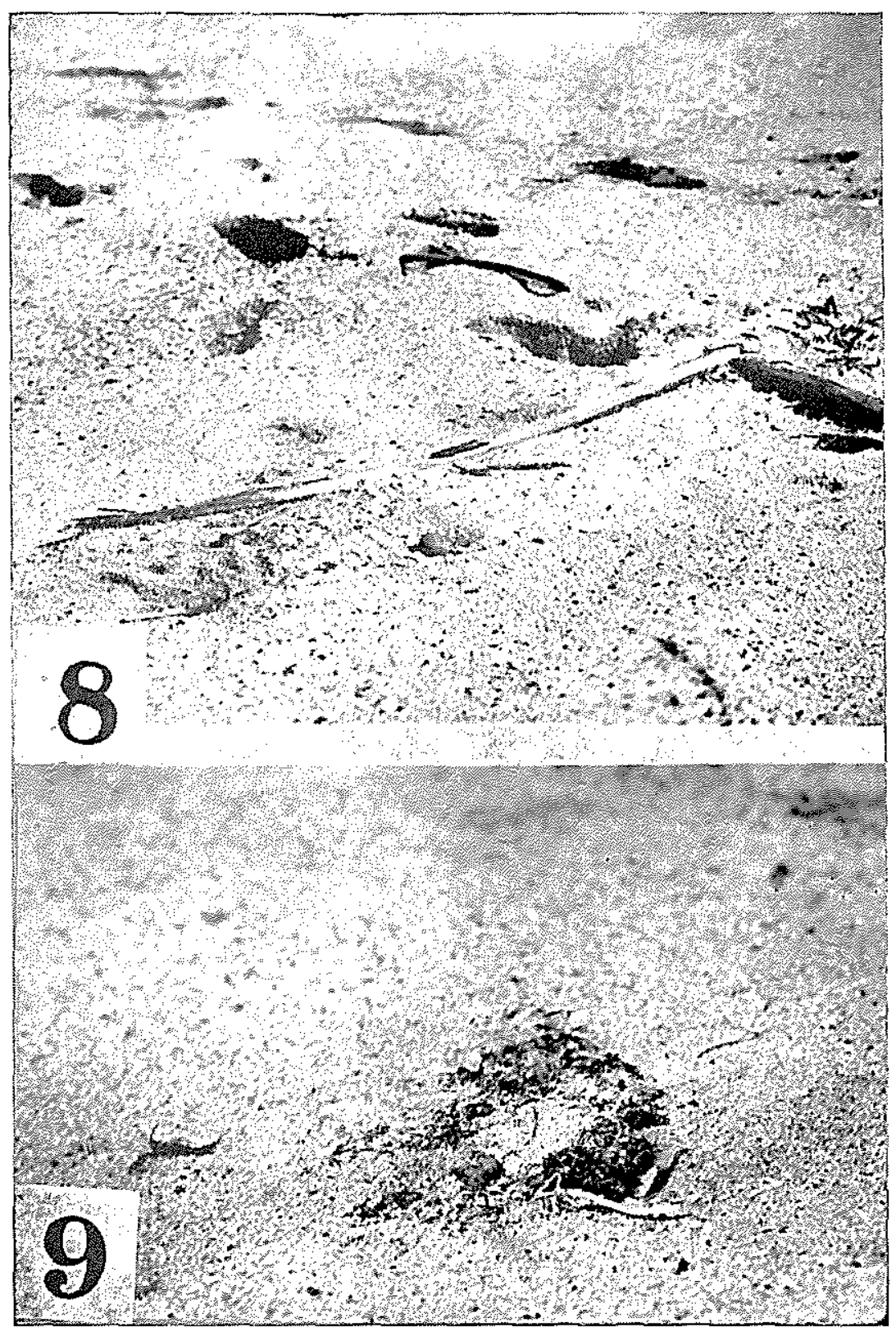




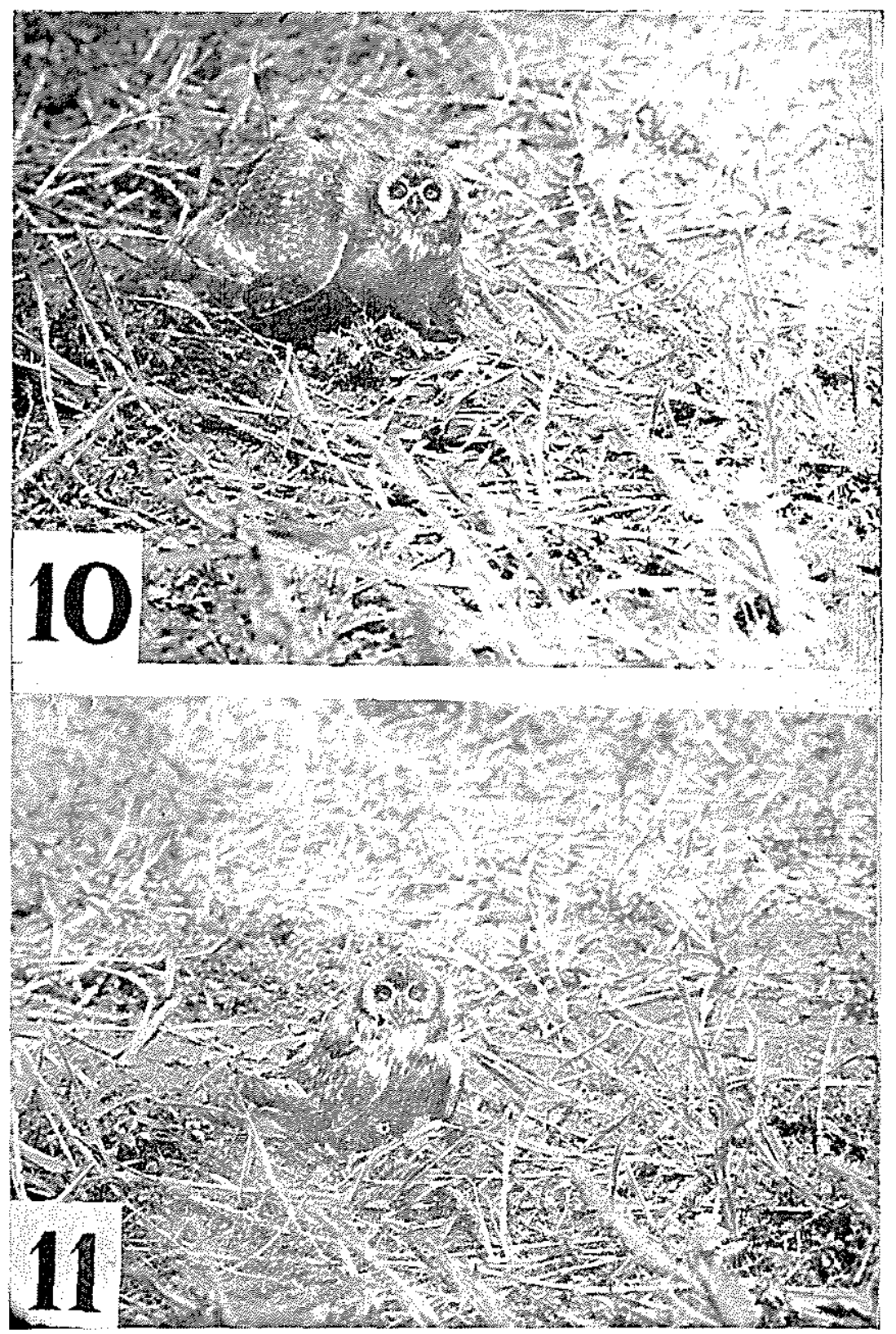




\section{PLATE VIII.}

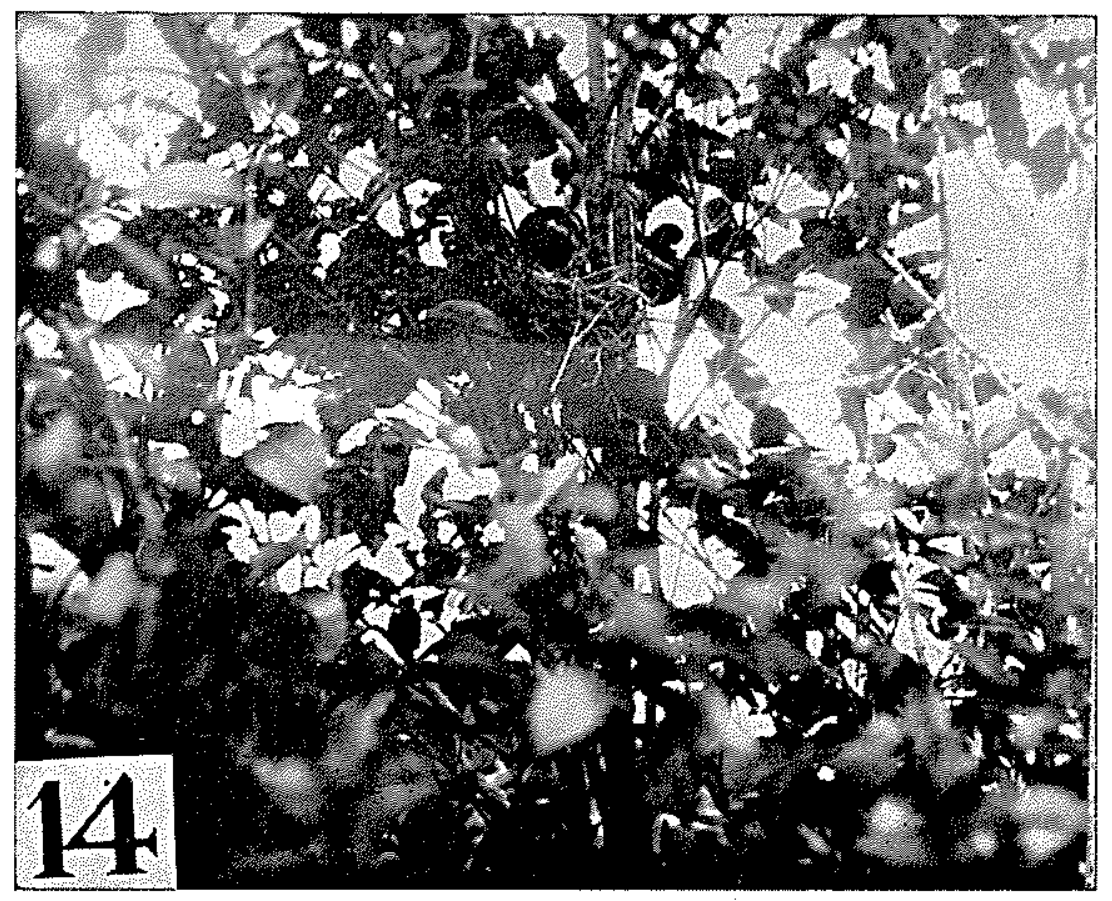




\section{Explanation of Plates}

Fig. 1. Map showing places visited for study.

Fig. 2. Brown Pelican in flight.

Cayo Enrique, August 15, 1927.

Photo by J. T. Emlen, Jr.

Fig. 3. Young Brown Pelicans in the nest.

Cayo Enrique, August 15, 1927.

Photo by J. T. Emlen, Jr.

Fig. 4. Common Booby on the nest.

Desecheo I'sland, May 8, 1927.

Photo by the author.

Fig. 5. Captive young Red-footed Booby from Desecheo Island.

May, 1927.

Photo by the author.

Fig. 6. Man-o-war Birds near their nests.

Cayo Enrique, August 15, 1927.

Photo by J. T. Emlen, Jr.

Fig. 7. Nest of Snowy Egret, with egg and newly hatched young.

Cayo Enrique, August 15, 1927.

Photo by J. T. Emlen, Jr.

Fig. 8. Egg of Least Tern.

Faro de Cabo Rojo, May 15, 1927.

Photo by the author.

Fig. 9. Nest and egg of Least Tern.

Faro de Cabo Rojo, May 15, 1927.

Photo by the author.

Fig. 10. Porto Rican Short-eared Owl.

Anegado Lagoon, September 29, 1926.

Photo by the author.

Fig. 11. Porto Rican Short-eared Owl.

Anegado Lagoon, September 29, 1926.

Photo by the author.

Fig. 12. Ne'st of Fork-tailed Hummingbird.

Maricao, November 8, 1926.

Photo by the author.

Fig. 13. Closer view of nest of Fork-tailed Hummingbird.

Maricao, November 8, 1926.

Photo by the author.

Fig. 14. Porto Rican Spindalis feeding young.

Algarrobo, March 22, 1927.

Photo by the author. 